\title{
Discussion Paper No. 2001/1
}

\section{The Impact of Adjustment-Related Social Funds on Income Distribution and Poverty}

\section{Giovanni Andrea Cornia ${ }^{1}$ and Sanjay Reddy ${ }^{2}$}

May 2001

\begin{abstract}
This study evaluates the impact of the over seventy Social Funds (SFs) which were introduced since the mid-1980s to offset the surge in poverty spurred by adjustment. SFs benefited from greater visibility and financial support by the donor community than traditional social security programmes, and raised expectations about ameliorating living conditions in many developing countries. Notwithstanding the greater administrative flexibility they enjoyed, and their fairly rapid implementation, SFs played a minor role in reducing the number of unemployed, adjustment- and chronicpoor, and in reversing adverse changes in income distribution. This was mainly due to the limited funding they received as well as to targeting, sequencing, and costeffectiveness problems. All in all, SFs have proven to be no panacea. Greater impact on poverty would have required greater resources, more permanent relief structures, improved planning and targeting and better timing in relation to the cuts entailed by adjustment. Most of all, public policy ought to have fostered greater congruence between the objectives of macroeconomic stability and social protection.
\end{abstract}

Keywords: fiscal policy, public expenditures, investment and finance, taxation, welfare programmes, provision and effect of welfare programmes

JEL classification: E62, H53, I38

\section{Copyright (C) UNU/WIDER 2001}

${ }^{1}$ University of Florence; ${ }^{2}$ Barnard College, Columbia University

This study has been prepared within the UNU/WIDER project on Rising Income Inequality and Poverty Reduction: Are They Compatible?, jointly sponsored by UNU/WIDER and the United Nations Development Programme (UNDP), and directed by Professor Giovanni Andrea Cornia.

UNU/WIDER gratefully acknowledges the financial contribution to the project by the Government of Sweden (Swedish International Development Cooperation Agency-Sida). 



\section{Introduction}

The eruption of the Asian crisis has once more brought to the fore the large social impact of ill-designed macroeconomic policies. Most poverty and inequality have deep rooted causes which can be removed only by structural (and by necessity slow) interventions such as land redistribution, educational expansion, the modernization of the tax system, and changes in the institutional structure of credit and property markets. However, apart from these deep-seated phenomena, it is now increasingly evident that structural adjustment, premature financial liberalization and unguided globalization can exacerbate poverty by inducing protracted recessions and macroeconomic instability.

By now it is broadly recognized that these policies - still viewed by many economists as efficient and even equitable over the long term - can be the cause of large increases in poverty and inequality over the short term and, in some cases, over the long term. One of the dominant responses to these new problems on the part of the institutions which have most advocated these policy changes has been the establishment of temporary social safety nets of a specific kind. These temporary social safety nets, known as Social Funds (SFs, hereafter) have become a prime policy choice for offsetting the negative social impact of policy reform. Indeed, 'strengthening of adjustment-related social safety nets' - as opposed to the development of permanent social protection systems or the introduction of adjustment approaches with a milder distributive impact-is one of the pillars of the current approach to policy reform.

It is accordingly paramount to assess the extent to which these programmes constitute an efficient antidote to the problems of increasing poverty and inequality often associated with policy reform. This assessment, however, is fraught with problems, not least because during their comparatively brief existence, their objectives, main activities, target population, funding patterns and institutional set-up have continuously evolved. Their impact also varies in relation to the strength of the social protection systems inherited from the pre-adjustment era, and to the impact of adjustment policies themselves which, in turn, have enjoyed varying degrees of success in different country settings. Finally, systematic data on social fund performance are still very difficult to find. 1

Despite these methodological difficulties, this paper argues that most SFs - particularly those of the first generation and those developed in sub-Saharan Africa-aroused misplaced expectations but played a minor role in containing unequalizing pressures arising from policy reform and in reducing the number of unemployed, 'adjustment poor' and 'chronic poor'. In addition, the emphasis placed on short-term SFs may have diverted resources and the attention of policymakers from the extension and reform of traditional formal social security arrangements.

1 This gap is being belatedly and gradually being remedied through studies such as the 'Social Funds 2000 Impact Evaluation' (see World Bank 1998), comprehensive results from which were not available at the time of writing of this paper. 


\section{Historical context leading to the mass introduction of Social Funds}

The 1980s and 1990s can be described as 'decades of policy reform'. The widespread balance of payments crises of 1981-84, the debt crisis of the mid-1980s, the simultaneous shift of the World Bank to structural adjustment lending, and the wave of restructuring and privatization programmes introduced in the former socialist economies of Europe were the main factors leading to a rapid increase in stabilization and structural adjustment programmes. A rough idea of the intensity of this effort can be grasped from the number of adjustment programmes carried out with the assistance of the Bretton Woods Institutions (BWI) during this period: while in the 1970s the number of countries initiating programmes with the support of the IMF averaged about 10 per year, it increased from 19 to 33 between 1980-85 (Cornia et al. 1987: 49). As a result, in the 1980s, the Latin American countries undertook an average of six adjustment programmes with the assistance of the BWI, while Jamaica, Mexico and Costa Rica undertook between 9 and 14 each. Likewise, in the 1980s, the African nations initiated an average of seven adjustment programmes, with Senegal, Kenya, Mauritius and Côte d'Ivoire undertaking between 12 and 15 (Jespersen 1992, Table 1.2). The effort at policy reform accelerated in the 1990s with the onset of the transition and the explosion of the 'Asian crisis'.

The poverty, distributive and growth impact of these reform programmes remains controversial. During the first half of the 1980s, adjustment focused mainly on restoring macroeconomic balance, as the BWI expected that this would lead to a rapid resumption of growth and poverty alleviation. It soon became apparent, however, that resumption of growth would take longer than initially expected, that adjustment caused at least a temporary increase in poverty and inequality and that, in the interim, measures were needed to offset these social costs (World Bank 1986). In 1990, the World Bank (1990: 23) formally acknowledged the need to develop special measures for social protection to accompany an unaltered approach to adjustment. The 'Social Funds' were the most prominent such measure.

Starting from 1987, a few developing countries started introducing semi-autonomous and fast-disbursing SFs aimed at compensating the 'adjustment poor' by means of anticyclical income maintenance and social expenditure programmes (with persistent stagnation, some of these programmes became semi-permanent). This is the phase which saw the development of the first sizeable Emergency Social Funds (SEFs) of Ghana and Bolivia. At a later stage, the distinction between 'adjustment poor' and 'chronic poor' started to be blurred and the scope of SFs was enlarged so as to address also the problems of the 'chronic poor' who, despite the adjustment reforms, were still being bypassed by growth.

In a third phase, the SFs increasingly shifted from 'compensatory' to 'promotive' measures, so as to incorporate the poor into the production process by increasing their human and physical assets. During this period one can trace the evolution of Social Emergency Funds (SEFs) into Social Investment Funds (SIFs) which effected, by and large, a programmatic shift from the objective of income generation to that of community-based provision of social services. 


\section{Impact of macroeconomic stabilization and policy reform on income distribution and poverty}

To what extent have SFs offset the distributive and poverty impact of policy reform? To reply to this question, we first have to discuss the social impact of policy reform. Since the early to mid-1980s an important part of the literature on inequality has focused on the distributive consequences of these reforms. The theoretical literature in this field comes to ambiguous conclusions. The distributive impact of adjustment is theoretically indeterminate, as it varies with the quality of existing institutions, human and physical infrastructure; the degree of diversification of the economy; the size, export-orientation and labour-intensity of the tradable sector; the elasticity of supply responses; and policy mix. In turn, the empirical literature reaches different conclusions depending on the methodology adopted (individual empirical case studies; cross-country regressions; or general equilibrium frameworks).

Yet, evidence reviewed in UNCTAD (1997), Kanbur and Lustig (1999), Behrman, Birdsall and Szekely (2000), Cornia with Kiiski (2001) and other studies suggests that inequality rose between 1980 and 2000 (or nearby years) in about two-thirds of the countries with adequate time series data. These findings are paralleled by evidence that inequality rose in line with policy reform in Africa and Latin America, including when poverty declined due to an acceleration of growth (Kanbur 1998). In what ways may each of the main policy instruments of orthodox adjustment have generated these social consequences? We take up this question in the remainder of this section. We review first the effect of macroeconomic stabilization and then discuss the impact of structural reforms.

\subsection{Macroeconomic stabilization}

While stabilization is in most cases necessary and unavoidable, its impact when brought about through conventional instruments - especially in developing countries - is unlikely to be distributionally favourable. Orthodox stabilization emphasizes demand constraining (fiscal and monetary restraint) as well as supply-enhancing (devaluation, elimination of price distortions and mobilization of resources) measures. The latter require time and investment to produce results, and face particularly formidable challenges in economies with a single dominant sector, weak institutions and infrastructure. While quickly restoring macroeconomic balance, demand management tends to generate recessions of varying duration (IMF 1998) and to entail changes which, though often with a sound rationale from a balance of payments viewpoint, tend to cause a fall in the wage rate and a rise in the profit rate (Johnson and Salop 1980). Unlike in the high-income countries, inequality in many types of developing countries rises during recessions (as wages are flexible downward, social safety nets are little developed and labour hoarding is rare) and falls during recoveries. As a result, under the recessions which are deliberately induced by demand contraction, wages often fall faster than GDP/capita and profits, the wage share declines and inequality of the size distribution of income worsens (the impact may be different, however, in dualistic economies with a small formal 'labour elite'). Indeed, Bourguignon and Morisson (1992) found evidence of an unequalizing trend of policy reforms in all analysed countries (except Malaysia) which had undertaken stabilization and structural 
adjustment programmes. Iglesias (1998) comes to similar conclusions for Latin America.

Inequality is often accentuated by the policies followed to control inflation. No doubt, hyperinflation causes a worsening of inequality. Yet, the inflation targets adopted in orthodox stabilization programmes are often single digit, even though the literature shows that below the threshold of 40 per cent a year inflation is not costly (Stiglitz 1998). Such ambitious targets are also achieved by means of large rises in interest rates and budget cuts which, as shown above, often have negative distributional effects.

Devaluation in particular can fail to have the effects anticipated in orthodox adjustment programmes for a diversity of reasons. In sectorally diversified less developed economies with an equitable asset distribution, well developed trade and transport infrastructure, and an abundant stock of educated labour, devaluation, export incentives and gradual trade liberalization generally have positive effects on growth, distribution and poverty reduction. In contrast, in poor primary commodity exporters, the same policies often have a different effect, due to the incomplete 'pass-through' of the benefits of devaluation to primary sector producers, the removal of second-best-optimal input subsidies and infrastructural supports which often accompanies devaluation and the effects of national policies on international prices. In the mining sector, for instance, long-run contracts specify the extent of the pass-through, so that it is the mining companies which largely benefit from devaluation in the intermediate term (Kanbur 1998). As well, in economies which are little diversified and whose exports do not depend on price competition but on the business cycle in the importing countries (such as some Sahelian economies), devaluation can have a contractionary effect as it may increase the price of essential imports for domestic production, while having little effect in stimulating non-price-competitive exports (see Krugman and Taylor 1978). Second, even in sectorally diversified economies, devaluation may increase inequality and have an ambiguous effect on poverty-for instance, in conditions in which the primary beneficiaries of increased export earnings are asset holders in the export-oriented industries and the goods consumed by workers are mostly imported.

\subsection{Structural reforms}

Evaluation of the impact of structural reforms is more complex and might lead to different conclusions depending on the specific instrument and region analysed. Yet, here too, there seem to be some regularities. For instance, when assessing the impact of the overall neoliberal policy package (proxied by a synthetic index measuring the intensity of the reforms) on wage differentials for 18 Latin American countries over 1980-98, Behrman, Birdsall and Szekely (2000) found that the overall structural package had a significant disequalizing effect which, however, tended to decline over time. Broadly similar evidence is provided by a review of the effects of liberalization and globalization during 21 reform episodes in 18 countries (13 from Latin America, three from Asia, Russia and Zimbabwe) over the last two decades (Taylor 2001). The study finds that inequality rose in 13 cases, remained broadly constant in six and improved only in two. Also this review confirms that inequality escalated in countries experiencing both a slow down or an acceleration of growth. All these studies, however, 
indicate that each main policy instrument (reviewed hereafter) may have a distinct effect.

\subsubsection{Trade liberalization}

Several studies find that trade distortions have a negative effect on distribution. Bourguignon and Morisson (1990) claim to show that the phased removal of trade protection reduces inequality, in line with the implications of orthodox trade theory as applied to relatively labour-abundant less developed countries. A similar view is offered by Wood (1994) who argues empirically that trade liberalization has raised inequality in the rich countries importing labour-intensive goods while reducing it in the developing countries exporting them.

However the empirical record in less developed countries offers a less sanguine view than these approaches grounded in orthodox theory suggest. Although conventional trade theory suggests that freer trade should reduce income inequality in the less developed countries due to the fillip it offers to production of labour-intensive goods, a more complete study of the empirical record seems to raise serious doubts about this view. Although diminishing income inequality was verified in East Asia in the 1960s and 1970s, the opposite has been observed in a broad range of LDCs over the last 20 years, including in the Asian exporters of labour-intensive manufactured goods (Cornia with Kiiski 2001). An array of studies indicates that wage differentials rose in line with liberalization in Latin America, the Philippines and a few OECD countries (Robbins 1995; Alarcon and McKinley 1995; Atkinson 1995; Harrison and Hanson 1999). Alternative theoretical approaches, such as those which stress structural inflexibilities, and the effect of trade on rent-sharing between employers and workers, can better explain these observations (see, for example, Rodrik 1997; Reddy and Dube 2000). Behrman, Birdsall and Szekely (2000) too explore a variety of factors that can erode the theoretical advantages of trade liberalization especially relevant to the case of Latin America. They focus on, among others, on the limited advantages enjoyed by lower middle-income regions in the export of labour-intensive goods in relation to those enjoyed by very low-wage economies such as China and other Asian countries. Empirically, their study finds no statistically significant relation between trade liberalization and wage differentials.

In a longer-term view of the effects of trade, Barro (1991) and Sachs and Warner (1995) found that trade distortions are associated with slow growth and therefore slow poverty reduction. Rodriguez and Rodrik (2000), however, take issue with the results of these studies arguing that they suffer from the omission of key variables and that, likely, there is not a clear relation between trade openness and growth.

\subsubsection{Liberalization of the labour market}

Even in periods of output expansion, distribution may deteriorate because of the impact of reforms promoting wage flexibility, reduced regulation and an erosion of minimum wages, unionization and collective bargaining. The impact of the liberalization of the labour market is often compounded by the removal of barriers to capital movements which increases the bargaining power of capital in its negotiations with both labour and 
government (Morley 2000). Empirical verification of such hypotheses is provided, among others, by Behrman, Birdsall and Szekely (2000) for 18 Latin American countries during the period 1985-95.

The liberalization of the labour market may generate a rise in both employment and wage dispersion, depending on the relative significance of the 'wage inequality effect' and the 'employment-creation effect', as well as on the relative roles of formal and informal sector labour. In the US, where employment rose rapidly, the fall in unionization accounted for about 20 per cent of the increase in inequality observed during the 1980s (Gottschalk and Smeeding 1997). In Eastern Europe, Latin America and the US, the decline of the minimum wage relative to the average wage is associated with a rise in overall inequality. These effects may be of some importance even in developing countries with smaller organized sectors than in the developed countries, especially when the effects of intra-family and other transfers across sectors are taken in to account.

\subsubsection{Domestic financial deregulation and the liberalization of the capital account}

Domestic financial sector reform has been one of the first structural policy changes introduced in a large number of developing countries. It began in the early 1970s in Latin America, spread to Africa and Asia in the 1980s and Eastern Europe in the 1990s. These changes in regulatory policies were conducive to private credit expansion but, with inadequate bank regulation and supervision in most countries, exacerbated the risk of banking crisis.

Domestic financial liberalization was followed by the liberalization of the capital account. In a growing number of countries such measure has generated a sharp social impact. This is in part due to the 'disciplining' structural effect such liberalization has on the policy (especially tax and redistribution) decisions of governments and the demands of organized labour, partly due to the real appreciation of the exchange rate (which was often associated with higher interest rates) which shifted resources to the non-tradable sector and increased subcontracting and wage cuts in the tradable sector, and partly to its tendency to increase the propensity to destabilizing financial crises with real effects. Recent evidence (Galbraith and $\mathrm{Lu}$ 1999) points to the relation between liberalization of the capital account, the frequency of financial crises and pursuant changes in earnings inequality and poverty, particularly in countries with weak labour institutions. In Latin America and Asia, for instance, financial crises raised inequality in 73 and 62 per cent of the time, while Finland, Norway and Spain experienced a sequence of banking and financial crises without experiencing increased inequality thereafter. In the empirical study on Latin America mentioned above, Behrman, Birdsall and Szekely (2000) find that the strongest disequalizing component of the overall reform package was precisely the capital account liberalization (followed by domestic financial liberalization and tax reform).

Financial liberalization tends also to have a deleterious impact on poverty. In Argentina, for instance, the poverty headcount ratio rose from 25.2 per cent in 1987 to 47.3 in the peak year to decline to 33.7 per cent in 1990 when the long-term growth path had recovered again (World Bank 2000b). This entailed a shift to a poverty level 8 
percentage points greater than prior to the crisis. Similarly the financial crises which hit Mexico between 1994 and 1996 and Russia between 1996 and 1998 respectively entailed rises in the poverty headcount ratio from 36.0 to 43.0 per cent and from 21.9 to 32.0 per cent (ibid). Thailand is an exception, in which after a comparatively sharp increase in poverty rates in 1997, the poverty rate in 1998 almost returned to the precrisis level of 12.9 per cent observed in 1996.

The above review highlights the complex linkages between various reforms and inequality and income deprivation. SFs were generally developed to offset the impact of stabilization and trade liberalization. However, as will be argued below, given their minuscule size and structural weaknesses, their impact on the nationwide distribution of income and poverty rates has likely been negligible.

\section{Adjustment related Social Funds: scale, scope and structure}

Since the first adjustment-related SF was launched in Bolivia in 1986, their number has burgeoned dramatically, as has their geographical reach. There now exist at least 70 SFs throughout the less developed and transition countries. ${ }^{2}$ SFs can be found in every major region, with some regions (notably Latin America) having become effectively 'saturated'. SFs are financial intermediaries which channel public funds to sub-projects administered by diverse actors. They do so, as will be described below, in a manner which is 'multisectoral' and 'demand-driven', in effect serving akin to general purpose public sector foundations.

In many contexts, SFs appear to have become the 'social development' instrument of choice. By the end of 1998, the World Bank alone had made commitments to SFs projects totalling over 1.5 billion US dollars and averaging $\$ 25$ million per project. This accounted for roughly 3 per cent of active bank projects, 1 per cent of its total financial commitments and 10 per cent of its annual commitments to the social sectors. 3 Similarly, the Inter-American Development Bank (IDB), had by 1997 lent over $\$ 1.3$ billion for SFs in the Americas, ultimately accounting for almost 15 per cent of its annual lending to the social sectors. Other external donors have also provided a sizeable amount. For example, of IDB financed SFs in Latin America, donors other than the World Bank and the IDB accounted for 18.4 per cent of total financing, amounting to a total of $\$ 801$ million through 1996.4 An illustration of the breadth of donor interest in SFs is provided by Egypt's SF, which has a total cost of $\$ 775$ million, of which 15.5 per cent is financed by the World Bank with the remainder provided by a patchwork of 16 donors and the government of Egypt. SFs have in general been heavily reliant on

2 Authors' calculations and personal communication from Soniya Carvalho, World Bank.

3 The latter figure is calculated by dividing the sum of fiscal year 1996 World Bank expenditure on education, health nutrition and population, and the 'social sectors' as identified in the 1998 World Bank Annual Report, by the value of social funds approved in fiscal year 1996 as identified in World Bank (1997).

4 Calculated by the authors on the basis of Table 2.1 in Goodman et al. (1997). 
external funding, averaging 88 per cent in Africa and 72 per cent in Latin America (UNCTAD 1994; Table 1 below).

SFs first became widespread in Latin America, and subsequently became common in Africa. More recently, however, they have been implemented in a number of Asian countries (notably Cambodia, Jordan, Mongolia, Pakistan and Thailand), and are being implemented in a number of low-income countries in transition (including Albania, Armenia, Georgia, Moldova, Romania, Tajikistan and Uzbekistan).

The multiplication of SFs around the world is an extraordinary example of a genuine institutional innovation finding rapid application in a range of countries. Although this is partly due to its ostensible applicability to the circumstances of developing countries, it is also due to having become a favourite instrument of officials in multilateral institutions. 5

As noted in the introduction, SFs have not always been adopted wholly uncritically, but rather have undergone considerable adaptation and innovation as they have been implemented in new settings and later years. As a result, the current generation of SFs bears only a 'family resemblance' to the very earliest ones. Current SFs fall into a number of distinct categories-Emergency Social Funds (SEFs), Social Investment funds (SIFs), and 'Agetips' - each representing innovations which have emerged over time so as to incorporate a number of new design features and modified objectives (see Reddy 1998 and Carvalho 1999 for some of the salient differences). Increasingly SEFs have been supplanted by SIFs which are seen as longer-term service delivery mechanisms whose ambit extends beyond the provision of infrastructure to that of general social programmes. 6 Despite this diversity, all SFs share two defining characteristics. They all are 'multisectoral' and 'demand-driven' financial intermediaries which provide public funds to external actors as a means of furthering social objectives.

The first shared characteristic — that SFs are meant to be 'demand-driven' — constitutes a genuine innovation with respect to previous anti-poverty and social service delivery instruments. An SF is 'demand-driven' if the projects financed by it are proposed by external entities such as NGOs, municipalities, and community organizations, acting on behalf of the potential beneficiaries. The SF may apply evaluation criteria of its own choosing to sift among these proposals and it may also assist these external organizations to prepare and submit proposals. Nevertheless the fund is demand-driven if it requires them to propose the projects that it finances. Although a demand-driven SF

5 The process of diffusion of the social fund model presents an informative case study in the process of transmission of development policy innovations both through the intermediation of international institutions and secondarily through unmediated 'South-South' cooperation. See Reddy (1997: 11) for a number of examples.

6 For example, Panama's FES supports programmes for street children, services for the elderly poor, and for abused women run by NGOs and community organizations, while Jamaica's SF funds drug rehabilitation and literacy programmes. Through such broader and more flexible initiatives, SFs are beginning to conform to a larger extent to the conceptual model of 'semi-autonomous public sector foundations'. 
relies for proposed projects on external organizations, it may or may not rely upon these organizations to implement them. In a traditional 'supply-driven' social programme, in contrast, the programme management identifies and designs projects. 7

The second shared characteristic - that SFs are generally 'multisectoral', in the sense that they finance activities which would otherwise fall under the jurisdiction of a variety of ministries-is less innovative but nevertheless distinctive. 8 It is not wholly innovative because previous multisectoral development programmes, such as the socalled integrated rural development programmes, have had a lengthy prior history. The SFs have financed activities ranging from the provision of health, education and water infrastructure and services, through to 'peace-building' efforts, skills generation, and the provision of micro-credit. 9 There is an intrinsic logical and practical link between the multisectoral character of SFs and the intent that they should be demand-driven. Relying solely upon counterparts to present project proposals of their own formulation requires openness to a range of possible formats and goals, which are difficult to accommodate within narrow sectoral boundaries. As a result, demand-driven SFs are usually administered by distinct decision-making bodies which are relatively independent of existing ministries. 10

There is little comparable or systematic evidence on the precise volume of funds spent on the various components of SF projects. However, a review of World Bank financed projects reports that roughly one-third of total project cost is allocated to 'economic infrastructure' and a similar proportion to social infrastructure and provision ('health nutrition and population', and education sectors), with the remaining one-third covering activities such as training, environmental interventions, and micro-finance (World Bank 1997). The figures for Latin American SFs contained in Grosh (1990) and in Goodman et al. (1997) in contrast suggest a rather higher average proportion allocated to social infrastructure and provision (respectively of 68 and 62 per cent). 11 This difference may

7 Although some degree of 'participation' may be incorporated in a project, it generally takes place in the context of predetermined guidelines formulated by the programme, which narrowly characterize the benefit to be delivered.

8 UNCTAD (1994) found that of 29 social funds surveyed, 28 were multisectoral (six had four or more types of projects, 20 had three or more types of projects, two had two or more types, and only one had a single type).

9 Social funds are gradually but continually expanding into new areas. For example, the Jamaica Social Investment Project has a menu of options including the financing of conflict resolution programmes, the creation and rehabilitation of 'integrated community spaces', and drug abuse counselling, all directed at reducing the level of urban violence (see 'Infrastructure Notes, Dec. 1996, World Bank).

10 Some recent sectoral projects incorporate demand-driven components inspired by the general social fund experience however. For instance, the Nepal Rural Water Supply and Sanitation project is specifically directed at water and sanitation projects (see Participation Sourcebook, World Bank 1999: chapter IV).

11 Authors' calculation based on calculating the average value of the sum of 'service provision' , and health, education and water/sewerage infrastructure lines of Table 6 in Reddy (1997) (derived from Grosh 1990), and by averaging the social infrastructure line for all funds for which complete data is available in Goodman et al. 1997. Note that this calculation generates a conservative estimate of expenditures on social infrastructure and provision as it does not include social assistance amounts which may be included in the 'other' category in the original tables. There may be differences of 
reflect continuing regional variation as the African SFs in particular (the 'Agetips') have tended to focus heavily on public works of a general kind. 12

SFs have been intended to serve diverse and changing objectives. The first generation of SFs (especially the 'SEFs') had focused mainly on the mitigation of the social costs of adjustment. However, as noted in the introduction, underlying this objective there were both a direct social rationale, and an indirect political rationale.

The direct social rationale was to recognize and counteract the deleterious impact of orthodox adjustment, which had been initiated in diverse countries under adverse economic circumstances and the intellectual influence of the 'Washington consensus'. This was attempted through SFs' financing of a combination of labour-intensive employment generation programmes, social expenditures aimed at counteracting direct fiscal retrenchment in the social sectors, and in certain cases programmes of retraining or direct compensation to those displaced by the adjustment process, especially from public employment.13As the social costs of adjustment mounted and became less deniable, SFs became the favoured answer to the question of how these costs were to be reduced.

The indirect political rationale for using SFs to mitigate the social costs of adjustment was to make the 'bitter pill' of adjustment easier to swallow. This consideration was explicitly a central one and is evinced in many documents and discussions of early SFs. It is well-known that the first SF, in Bolivia, was initiated in large part as a result of the forceful conviction of a World Bank consultant who was an ex-politician (a British member of Parliament) who argued that it was necessary to undertake 'highly visible action' to mitigate the social costs of adjustment in order to make the latter more

definition between the three sources considered in this paragraph which limit the possibilities for comparison. It is difficult to tell as the definition of categories has not been made explicit in all of the sources.

12 For suggestive evidence, see Marc et al. (1995: Table A.3). In Senegal Agetip I and Senegal Agetip II for instance, 'labor intensive works' take up between 70 and 84 of overall expenditures. It is not possible to distinguish the social from economic infrastructure components of 'labor intensive works' (e.g. schools vs. roads). Descriptive evidence suggests however that the Agetips have placed no special priority on the former.

13 A somewhat incoherent distinction made frequently in this period was between the so-called 'new poor' and the so-called 'old poor'. The so-called 'new poor' (really the 'newly poorer') refers to individual such as retrenched civil servants made poorer by the adjustment process though they may not have fallen below the poverty line. The old poor, in contrast, refers to those who may or may not have been negatively affected by the adjustment process, but were already below the poverty line. As a result, not all of the newly poorer are in fact poor and not all of the newly poorer are in fact new to poverty. The distinction between new poor and old poor is therefore quite misleading. Nevertheless, it has been widely used in the literature on social funds. A significant debate has taken place as to whether social funds should be targeted at the new poor or the old poor. In any event, it is likely that social funds failed to reach the 'new poor'. For example, evidence shows that in the case of the Bolivian emergency social fund, of the very large number of tin miners who lost their jobs during the adjustment process, a very small percentage (likely less than two percent) came to be employed on its projects. Admittedly, 'The ESF did not target the ex-employees of the public sector who are generally considered to have been the persons most directly affected by Bolivia's structural adjustment program' (Newman et al. 1992 in Jorgensen at al. 1992). 
politically palatable.14 The often close link between SF management and the executive branch of governments (the former typically reported directly to the latter rather than to existing ministries) owes its origin in part to the perceived need for the national political leadership to be able to 'claim credit' for SF achievements. One version of this argument which has been influentially made is that SFs help to create so-called 'new coalitions for reform' composed of those benefiting from the fund, who may well be distinct from those injured by the adjustment process. The former, if sufficiently numerous, can aid the political viability of the reform package even if it continues to harm others. 15 A 'less cynical' version of this argument noted by Cornia (1999) is that 'if the government was not able to generate enough popular support for the economic reforms, it would not have been able to sustain any adjustment programme, without which the poor would have suffered even more because of a likely return to unsound macro policies'.

As the purpose of this paper is to examine the role of SFs as an anti-poverty device, and especially as a response to the social costs of adjustment, it is only necessary to mention briefly the other objectives upon which SFs have increasingly focussed. Indeed, the 'compensatory' role of SFs is today scarcely mentioned, although their pivotal role in the multilateral response to the 'Asian crisis' testifies that they still are seen as potentially playing this role.16 That the 'emergency response' role of SFs is of continued importance is also testified to by the reliance upon them as mechanisms with which to respond to natural disaster and post-conflict reconstruction needs. 17 SFs are increasingly conceived as an intermediate and long-term service delivery instrument which is more efficient than traditional means of service delivery through established ministries, through their employment of an ostensibly more participatory, decentralized, and 'demand-responsive' approach. In this connection, they have been seen as everything from a 'beachhead' for the 'modernization of the state' (through the 'demonstration effect' they have on ineffectual state bureaucracies) to a 'training ground in the democratic process' (Benería and Mendoza 1995). These diverse claims, which are themselves controversial and call for more systematic evaluation, are not all taken up here (for independent evaluations see Goodman et al. 1997, Reddy (1998), and Tendler (1999).

Despite the diversity of claims made on behalf of current SFs, they almost all continue to claim to have ultimately an anti-poverty objective, whether through alleviating short-run hardship or bringing about more sustainable and efficient delivery of social

14 See Marshall (1992) in Jorgensen et al. (1992).

15 See Graham (1994). It is not clear how this argument can be reconciled with our knowledge of the small numbers of people affected by social funds (see next section) unless the argument rests on there being a powerful symbolic appeal to the creation of social funds.

16 See in particular the 'social investment fund' component of the $\$ 300$ million 'social investment project' for Thailand proposed by the World Bank ('Project Appraisal Document, Report No. 17785 $\mathrm{TH})$.

17 On the ostensible emergency role of SFs in Central America (Honduras, Nicaragua, and Guatemala) in the aftermath of 'Hurricane Mitch' see World Bank (2000). For their role in post-conflict Cambodia, see Virak (2000). 
services. It is therefore important to attempt comprehensively to judge the claim that they help meaningfully to reduce inequality and poverty.

\section{Effects on incomes and poverty: macro-perspective}

Have the resources assigned to SFs been adequate to contend with the scale of social costs entailed by adjustment, and the social needs in developing countries? Real programme expenditures on SFs are difficult to enumerate on a strictly comparable basis. However, some rough comparisons are possible. It appears that the scale of SFs has varied substantially, from 6 to 85 million US dollars in the case of Africa, and from 40 million to 2.5 billion dollars in the case of Latin America (Marc et al. 1995: Annex 1, Table A.5; Table 1 below)

If the expenditure on SFs is examined as a percentage of GDP, their small scale is even more evident. Of the countries included in Table 1, in no case do SF resources per programme year rise above 1 per cent of GDP. Their scale in relation to GDP appears to have been somewhat lower in Africa (between 0.1 and 0.4 per cent per programme year) than in L. America (between 0.4 and 1 per cent). As a share of social expenditure, SFs have accounted from 0.3 per cent in the case of Chile to 11 per cent in the case of Bolivia's Emergency Social Fund, in the sample shown in Table 2. It can be observed that in Africa this share has ranged more narrowly between 1.7 and 7.4 per cent.

It is interesting and important to note that during the years of SFs, total social expenditure (either as a percentage of GDP or on a per capita basis) declined in four cases (Panama, Ecuador, El Salvador and Zambia) out of 12 in Table 1, rose by an amount less than or equal to the expenditure on SFs in two cases (Bolivia and Madagascar - it is conceivable that some diversion from regular social expenditure to social funds might have occurred here), and rose in the remaining six. This muddy picture suggests that the claim that SFs have arrested the decline in aggregate social expenditure may be difficult to sustain. This result may be viewed more unfavourably still when the initial year of comparison is allowed to vary. When the comparison is carried out in relation to a suitable pre-adjustment period (for example 1979-1981, which preceded the mass of adjustment programmes), rather than the relatively depressed interval 1987-89, it no longer appears that SFs have in fact offset the fall in social expenditure as a percentage of GDP or indeed of social expenditure per capita (Table 1 and Table 2). In this broader comparison, in 10 cases out of the 14 included in Table 2, the additional expenditure on SFs failed to compensate for the initial fall in social expenditure or was not able to arrest its declining trend. This fact takes on even more importance in light of the fact that the needs of the populations of the countries concerned are likely to have been heightened by their declining incomes and increased insecurity as a result of the adjustment process.

A third way to assess the scale of SFs might consist in comparing their yearly expenditure with the increase in the 'poverty gap' over the years in questions entailed by stabilization or structural adjustment. This measure would best capture the extent to which SFs were able to compensate the social cost of adjustment. Information on the increase in the poverty gap for the countries which have introduced SFs is however not 
available. Conclusions about the adequacy of the funds allocated would depend, in addition, on the precision of the targeting of the SFs which, as it will be noted later, has often been poor.

Table 1

Expenditure on selected social funds (SF) as percentage of GDP and social expenditure (SE), social expenditure/GDP ratio, real social expenditure per capita in selected Latin American and African countries

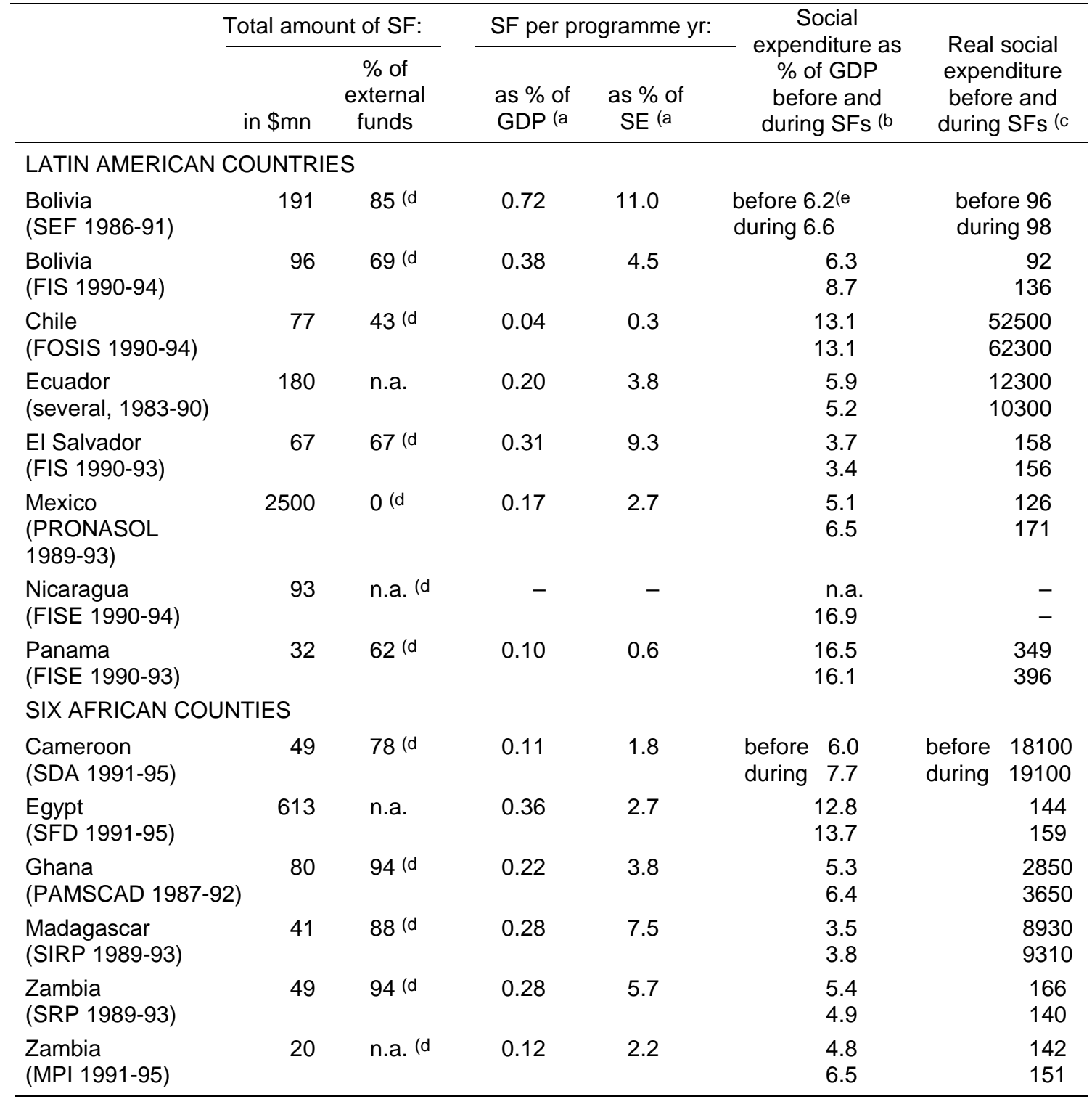

Source: $\quad$ Cornia (1999) based on data in UNCTAD (1994); Glaessner et al. (1994); Marc et al. (1995);

Notes: (a Total value of SF (divided by the number of years of operations) and further divided by the average yearly GDP of the period considered;

(b 'Before' = average social expenditure/GDP ratio over the two years preceding the onset of the SFs (social expenditure includes health, education, social security, housing, and other amenities), 'during' = unweighted average during the programme years;

(c 'Before' = average real social expenditure per capita (in national currency in constant 1987 prices) over the two years preceding the onset of the SFs, 'during' = unweighted average during the programme years;

(d Share of SFs funded with foreign, NGOs and other resources; (e $1983-84$. 

Table 2

Social expenditure/GDP ratio and social expenditure per capita in constant prices pre-crisis/adjustment, 2 years before the launch of SFs and during the SFs

\begin{tabular}{|c|c|c|c|c|c|c|}
\hline $\begin{array}{l}\text { Country } \\
\text { SFs and years }\end{array}$ & $\begin{array}{l}\text { SE/GDP, } \\
\text { pre-crisis \& adjustment (a }\end{array}$ & $\begin{array}{c}\text { SE/GDP } \\
2 \text { years prior SF }(a\end{array}$ & $\begin{array}{l}\text { SE/GDP } \\
\text { during SF (a }\end{array}$ & $\begin{array}{c}\text { SE per capita, } \\
\text { pre-crisis \& adjustment (b }\end{array}$ & $\begin{array}{l}\text { SE per capita, } \\
2 \text { years prior SF }(b\end{array}$ & $\begin{array}{l}\text { SE per capita } \\
\text { during SF }(b\end{array}$ \\
\hline $\begin{array}{l}\text { Bolivia } \\
\text { FSE, 1986-91 }\end{array}$ & $\begin{array}{c}6.0 \\
(1978-80)\end{array}$ & $\begin{array}{c}6.2 \\
(1983-84)\end{array}$ & $\begin{array}{c}6.6 \\
(1986-91)\end{array}$ & $\begin{array}{c}111 \\
(1978-80)\end{array}$ & $\begin{array}{c}96 \\
(1983-84)\end{array}$ & $\begin{array}{c}98 \\
(1986-91)\end{array}$ \\
\hline $\begin{array}{l}\text { Bolivia } \\
\text { FIS, 1990-94 }\end{array}$ & $\begin{array}{c}6.0 \\
(1978-80)\end{array}$ & $\begin{array}{c}6.3 \\
(1988-89)\end{array}$ & $\begin{array}{c}8.7 \\
(1990-94)\end{array}$ & $\begin{array}{c}111 \\
(1978-80)\end{array}$ & $\begin{array}{c}92 \\
(1983-84)\end{array}$ & $\begin{array}{c}136 \\
(1990-94)\end{array}$ \\
\hline $\begin{array}{l}\text { Chile } \\
\text { FOSIS, 1990-94 }\end{array}$ & $\begin{array}{c}19.3 \\
(1980-82)\end{array}$ & $\begin{array}{c}13.1 \\
(1988-89)\end{array}$ & $\begin{array}{c}13.1 \\
(1990-94)\end{array}$ & $\begin{array}{c}65800 \\
(1980-82)\end{array}$ & $\begin{array}{c}52500 \\
(1988-89)\end{array}$ & $\begin{array}{c}62300 \\
(1990-94)\end{array}$ \\
\hline $\begin{array}{l}\text { Ecuador } \\
\text { Several, 1983-90 }\end{array}$ & $\begin{array}{c}5.9 \\
(1980-82)\end{array}$ & $\begin{array}{c}5.7 \\
(1981-82)\end{array}$ & $\begin{array}{c}5.2 \\
(1983-90)\end{array}$ & $\begin{array}{c}12300 \\
(1980-82)\end{array}$ & $\begin{array}{c}12000 \\
(1981-82)\end{array}$ & $\begin{array}{c}10300 \\
(1983-90)\end{array}$ \\
\hline $\begin{array}{l}\text { El Salvador } \\
\text { FIS, } 1990-93\end{array}$ & $\begin{array}{c}6.1 \\
(1980-82)\end{array}$ & $\begin{array}{c}3.7 \\
(1988-89)\end{array}$ & $\begin{array}{c}3.4 \\
(1990-93)\end{array}$ & $\begin{array}{c}284 \\
(1980-82)\end{array}$ & $\begin{array}{c}158 \\
(1988-89)\end{array}$ & $\begin{array}{c}156 \\
(1990-93)\end{array}$ \\
\hline $\begin{array}{l}\text { Mexico } \\
\text { Pronasol, 1989-93 }\end{array}$ & $\begin{array}{c}7.5 \\
(1980-82)\end{array}$ & $\begin{array}{c}5.1 \\
(1987-88)\end{array}$ & $\begin{array}{c}6.5 \\
(1989-93)\end{array}$ & $\begin{array}{c}208 \\
(1980-82)\end{array}$ & $\begin{array}{c}126 \\
(1987-88)\end{array}$ & $\begin{array}{c}171 \\
(1989-93)\end{array}$ \\
\hline $\begin{array}{l}\text { Nicaragua }{ }^{(c} \\
\text { FISE, 1990-94 }\end{array}$ & $\begin{array}{c}3.9 \\
(1978-80)\end{array}$ & - & $\begin{array}{c}16.9 \\
(1990-94)\end{array}$ & $\begin{array}{c}- \\
(1978-80)\end{array}$ & - & $(1990-94)$ \\
\hline $\begin{array}{l}\text { Panama } \\
\text { FSE, 1990-93 }\end{array}$ & $\begin{array}{c}14.8 \\
(1985-87)\end{array}$ & $\begin{array}{c}16.5 \\
(1988-89)\end{array}$ & $\begin{array}{c}16.1 \\
(1990-93)\end{array}$ & $\begin{array}{c}377 \\
(1985-87)\end{array}$ & $\begin{array}{c}349 \\
(1988-89)\end{array}$ & $\begin{array}{c}396 \\
(1990-93)\end{array}$ \\
\hline $\begin{array}{l}\text { Cameroon } \\
\text { SDA, 1991-95 }\end{array}$ & $\begin{array}{c}6.8 \\
(1985-87)\end{array}$ & $\begin{array}{c}6.0 \\
(1989-90)\end{array}$ & $\begin{array}{c}7.7 \\
(1991-95)\end{array}$ & $\begin{array}{c}25700 \\
(1985-87)\end{array}$ & $\begin{array}{c}18100 \\
(1989-90)\end{array}$ & $\begin{array}{c}19100 \\
(1991-95)\end{array}$ \\
\hline $\begin{array}{l}\text { Egypt } \\
\text { SFD, 1991-94 }\end{array}$ & $\begin{array}{c}16.7 \\
(1981-83)\end{array}$ & $\begin{array}{c}12.8 \\
(1989-90)\end{array}$ & $\begin{array}{c}13.7 \\
(1991-94)\end{array}$ & $\begin{array}{c}156 \\
(1981-83)\end{array}$ & $\begin{array}{c}144 \\
(1989-90)\end{array}$ & $\begin{array}{c}159 \\
(1991-94)\end{array}$ \\
\hline $\begin{array}{l}\text { Ghana } \\
\text { Pamscad, 1987-92 }\end{array}$ & $\begin{array}{c}6.4 \\
(1977-78)\end{array}$ & $\begin{array}{c}5.3 \\
(1985-86)\end{array}$ & $\begin{array}{c}6.4 \\
(1987-92)\end{array}$ & $\begin{array}{c}4130 \\
(1977-78)\end{array}$ & $\begin{array}{c}2850 \\
(1985-86)\end{array}$ & $\begin{array}{c}3650 \\
(1987-92)\end{array}$ \\
\hline $\begin{array}{l}\text { Madagascar } \\
\text { SIRP, 1989-93 }\end{array}$ & - & $\begin{array}{c}3.5 \\
(1988)\end{array}$ & $\begin{array}{c}3.8 \\
(1989-93)\end{array}$ & - & $\begin{array}{c}8930 \\
(1988)\end{array}$ & $\begin{array}{c}9310 \\
(1989-93)\end{array}$ \\
\hline $\begin{array}{l}\text { Zambia } \\
\text { SRP, 1989-93 }\end{array}$ & $\begin{array}{c}9.5 \\
(1976-82)\end{array}$ & $\begin{array}{c}5.4 \\
(1987-88)\end{array}$ & $\begin{array}{c}4.9 \\
(1989-93)\end{array}$ & $\begin{array}{c}358 \\
(1976-82)\end{array}$ & $\begin{array}{c}166 \\
(1987-88)\end{array}$ & $\begin{array}{c}140 \\
(1989-93)\end{array}$ \\
\hline $\begin{array}{l}\text { Zambia } \\
\text { MPI, 1991-95 }\end{array}$ & $\begin{array}{c}9.5 \\
(1976-82)\end{array}$ & $\begin{array}{c}4.8 \\
(1989-90)\end{array}$ & $\begin{array}{c}5.8 \\
(1991-95)\end{array}$ & $\begin{array}{c}358 \\
(1976-82)\end{array}$ & $\begin{array}{c}142 \\
(1989-90)\end{array}$ & $\begin{array}{c}151 \\
(1991-95)\end{array}$ \\
\hline
\end{tabular}

Source: Cornia (1999) based on IMF GFS 1987,1991,1997; IMF IFS 1997; WB World Development Indicators 1998.

Notes: (a In percentages; (b Social Expenditure per capita in constant 1987 local currency units; (c For Nicaragua comparisons are made difficult as in $1990-91$ a new currency and a large devaluation were introduced, and the war ended. 

Table 3

Maximum possible average expenditure per poor person by SFs

in selected countries

\begin{tabular}{lc}
\hline Social Fund & Amount (US\$) \\
\hline Bolivia, FSE & 9 \\
Bolivia, FIS & 7 \\
Chile, FOSIS & 30 \\
Dominican Republic, PROCOMUN & 7 \\
Ecuador, FISE & 6 \\
El Salvador, FIS & 11 \\
Ghana, PAMSCAD & 19.5 \\
Guatemala, FONAPAZ & 3 \\
Guatemala, FIS & 3 \\
Haiti, FAES & 3 \\
Honduras, FHIS & 7 \\
Madagascar & 7.5 \\
Mexico, PRONASOL & 135 \\
Nicaragua, FISE & 11 \\
Peru, FONCODES & 11 \\
Panama, FES & 16 \\
Senegal & 3.5 \\
Uruguay, PRIS/FAS & 62 \\
Zambia & $<1$ \\
Zimbabwe & $<1$ \\
\hline
\end{tabular}

Sources: Graham (1994); Stewart and van der Geest (1995); Goodman et al. (1997).

Other similar indicators of the scale of SFs are also telling. For instance, the absolute levels of annual disbursements per poor person through SFs are generally small. Table 3 shows that these vary from $<\$ 1$ (Zimbabwe and Zambia) to an exceptional $\$ 135$ (Mexico's Pronasol), and averages less than $\$ 18$ per poor person. This record of the maximum amounts SFs have actually been capable of making available to the poor is perhaps the most damaging indictment of the somewhat grandiose claim that they could effectively cushion the poor from the adverse economic consequences of adjustment.

Similarly, Table 4 shows that the employment created per year by SFs in Latin America as a fraction of the labour force varied from 0.1 to 1 per cent. This data is equally severely damaging to the image of SFs as safety nets for the poor. It is also reported that in Honduras (1990-95) SF-generated employment amounted to 7 per cent of the unemployed, in Peru (1991-95) to 2.7 per cent, and in El Salvador (1990 onward) to 2.5 per cent (Tendler 2000). It is difficult to view these levels of impact on employment as sizeable, or as likely to serve a meaningful compensatory function under the social strains generated by crisis and orthodox adjustment.

Finally, SFs meant to compensate for the social costs of adjustment have often been very slow to begin functioning, seriously prejudicing their ability to achieve their proclaimed short-term purpose. Ghana's PAMSCAD, the first major effort in Africa to 
mitigate the social costs of adjustment through compensatory action, was notoriously slow to begin to operate, casting much doubt on its value. Tendler (1999) also reports that many traditional social programmes appear to have disbursed funds more rapidly than SFs, contrary to a common conception. This may in large part be due precisely to the commendable attempt of SFs to be 'participatory' and 'demand-driven'. Of course this does not suggest that participation is an undesirable goal-only that SFs and other institutional mechanisms which attempt to instantiate it may not be the most suitable vehicles for providing emergency compensation to the poor. SFs are an inadequate response to emergencies both because their administrative structures take time to establish and because counterparts take time to organize themselves and to identify and formulate projects. Whether or not SFs are a viable instrument of long-term service delivery, they are patently inadequate as compensatory devices for short-term shocks. A more suitable institutional arrangement to contend with such shocks would be previously established standing social protection institutions which are capable of expanding rapidly the supply of social protection services, when required, at low marginal costs, even if the fixed costs entailed in creating such institutions are somewhat higher. Some arrangements of this type are discussed in (Section VI) below, which would serve to reduce a pervasive problem of SFs: that protection delayed is protection denied.

Table 4

Employment creation in Latin American Social Funds

\begin{tabular}{lc}
\hline Social Fund & Social Fund employment as a fraction of labour force $(\%)$ \\
\hline Bolivia, FES & 1.0 \\
Bolivia, FIS & 0.1 \\
Chile, FOSIS & negligible \\
Ecuador, FISE & 0.2 \\
El Salvador, FIS & 0.3 \\
Guatemala, FIS & 0.3 \\
Haiti, FAES & 0.3 \\
Honduras, FHIS & 0.8 \\
Nicaragua, FISE & 0.6 \\
Peru, FONCODES & 0.2 \\
Panama, FES & 0.2 \\
\hline
\end{tabular}

Source: Goodman et al. (1997).

\section{Effects on incomes and poverty: micro-perspectives}

It has been argued above that, in general, SFs have not disposed of the aggregate resources necessary to meet their proclaimed anti-poverty objectives. However, if they had had larger resources, would it have been possible for them to meet these objectives? Are SFs in fact more efficient and even equitable per unit expenditure than traditional anti-poverty instruments, as frequently argued? After almost one and a half decade, the 
data with which to answer these questions remains limited.18 However, it is now possible to make, with some confidence, some preliminary judgements in this regard.

Any anti-poverty intervention generates a stream of costs and benefits, distributed over people and time. The key questions in assessing the intervention are then: who benefits and who pays? How much? When and for how long? How does this intervention compare to others on each of these criteria? In the following, we attempt a preliminary approach to the micro-assessment of SFs, guided by these questions.

\subsection{Transfer and cost efficiency}

A widespread claim on behalf of SFs has been that unit costs of the infrastructure and services that they provide are lower than under traditional governmental programmes. There is little direct documentary evidence for this claim however. In any event, it is usually overlooked that a proper accounting of costs should include both the costs undertaken by the counterpart as well as those of the SF. Including counterpart costs would tend to increase substantially unit-cost estimates for SFs. With this caveat, a degree of evidence is available of the cost associated with one of the objectives of SFs, namely employment generation (see Table 5).

Although these costs are difficult to interpret as they include all programme costs, including those for administration and materials, and do not correct for purchasing power parity, they are often relatively high (averaging $\$ 17$ per person-day of employment), and do not appear to compare favourably to those of traditional 'supplydriven' employment generation schemes. For instance India's 'supply-driven' Jawahar Rozgar Yojana scheme has a cost of roughly $\$ 1.5$ per person-day of employment created (Authors' calculation based on Government of India Economic Survey for 199899). Indirect evidence of the cost efficiency of SFs service delivery is however available in the form of the reported administrative costs of some funds. Table 6 summarizes these data.

Glaessner et al. (1994) report that the administrative costs of most SIFs in L. America amounted to ' 8 to 13 per cent of the annual commitments once they reached a relatively high level of activity'. The internal comparison of the administrative costs of different funds is complicated by the use of different accounting conventions (Cisneros 1993 quoted in Glaessner et al. 1994). Nevertheless, it does seem that their administrative costs may be relatively low as compared to traditional governmental ministries and agencies. This evidence must be interpreted with great caution however. SFs administrative costs do not include the direct and opportunity costs to counterparts of executing projects. The administrative costs of traditional approaches to delivering social services in final form to communities cannot therefore be straightforwardly

18 By far the best publicly documented social fund remains the first, the Bolivian Emergency Social Fund (see Jorgensen et al. 1992). Elementary data on such fundamental matters as unit costs, the distribution of economic status of beneficiaries, and the composition of expenditures remains generally lacking. Efforts to fill these gaping lacunae would enable a more realistic assessment of the claims made on their behalf and a more comprehensive assessment of the value of social funds. 
compared with those of SFs, the work of which may consist only in promoting, selecting and financing sub-projects, but not in executing them.

Table 5

Costs of employment generation

\begin{tabular}{lc}
\hline Social Fund & Total cost per person-day of employment (US\$) \\
\hline Senegal, Agetip & 18.3 \\
Madagascar, EMSAP & 3.0 \\
Guinea Bissau, SIRP & 19.1 \\
Ghana, PAPSCA & 8.4 \\
Bolivia, ESF & 9.8 \\
Bolivia, FIS & 41.3 \\
Nicaragua, FISE & 30.0 \\
El Salvador, FIS & 20.7 \\
Haiti, FAES & 3.5 \\
\hline
\end{tabular}

Sources: Authors' calculations based on Jorgensen et al. (1992); Glaessner et al. (1994); Marc et al. (1995), and Goodman et al. (1997). Where there were discrepancies between the figures implicit in these different sources, the authors used the most reasonable estimates based on regional comparisons and internal consistency of data. In order to generate comparable data estimates, it was assumed that a person-year contains 12 person-months and 300 person-days.

Table 6

Reported administrative costs as a share of expenditure

\begin{tabular}{lc}
\hline Social Fund & Percentage \\
\hline Bolivia, ESF & 5.5 \\
Bolivia, SIF & 9 \\
Honduras, FHIS & $8-14$ \\
Honduras, ESF & 9 \\
Haiti, ESF & 10 \\
Guatemala, SIF & 10 \\
Senegal, Agetip & 5 \\
Zambia, SRF & 12 \\
Sao Tome, SIF & 15 \\
Guinea Bissau, SIRP & 26 \\
\hline Sources: Grosh (1990); ILO (1992); Jayarajah et al. (1996); Stewart and van der Geest (1995); UNCTAD \\
\multicolumn{1}{c}{ (1994); Marc et al. (1995); Glaessner et al. (1994). }
\end{tabular}

\subsection{Targeting efficiency}

The appropriate targeting of benefits delivered is a central issue in designing and evaluating any programme meant to benefit the poor. The goals of ensuring that as many intended beneficiaries as possible are reached (minimizing 'errors of exclusion' or F-errors), and that as few unintended beneficiaries as possible are reached ('minimizing 
'errors of inclusion' or E-errors), are paramount.19 The goal of targeting benefits effectively is closely connected with the more general goal of achieving equity in the distribution of benefits. An efficient and equitable anti-poverty programme will reach both as many of the poor as possible (minimize F-errors) and benefit as few of the nonpoor as possible (minimize E-errors). Where there is a tradeoff between achieving these two objectives, the relative balance of objectives in any specific anti-poverty programmes remains in principle to be decided (if only so as to safeguard funds for other anti-poverty programmes) although anti-poverty policy as a whole must, by definition, be directed toward minimizing errors of exclusion.20 SFs are targeted (although not necessarily well-targeted) programmes, insofar as one of the criteria used in selecting sub-projects is whether potential beneficiaries are poor.

SFs may suffer from errors of exclusion which are sizeable for a number of reasons. Firstly, even if they have the alleviation of poverty as their sole objective (which the Agetips for instance typically do not), their resources may simply be insufficient. Secondly, even if they were to have sufficient resources to reach the poor, the ability of SF administrators to sort among project proposals according to the extent of deprivation of the proposed beneficiaries, may be severely limited due to incomplete information. Thirdly, poor communities may be less capable than less deprived ones of effectively identifying viable projects and articulating their demands. The first two problems are generic ones. The last is intrinsic and particular to so-called 'demand-driven' programme such as SFs. It is likely that both the first and third problems have been especially severe ones for SFs. As argued in the previous section, the resources available to them have been small in aggregate. The difficulties they have had in eliciting proposals of high quality equally from communities varying in the extent of their deprivation are also now well known.

In practice, the quality of targeting of SFs has been mixed. The analysis here focuses on direct beneficiaries of SFs, not because mechanisms which generate indirect impact (for instance through pecuniary externalities and multiplier effects of SF activity on labour and good markets) but because there is no sound basis for estimating these, and because they are likely to be roughly proportional to the direct effects identified here. Bolivia's SEF has been by far the best documented social fund in this respect. It was found that employees in positions generated by the SEF were overwhelmingly 'prime-age' (20-65 years), married (71 per cent), male (99 per cent), and largely the sole income-earners in

19 The terms F errors and E errors are used by Cornia and Stewart (1993), to describe errors of exclusion ('(F)ailing beneficiaries') and errors of inclusion ('(E)xcess benefits') respectively. Besley and Kanbur (1988), and Sen (1994) use alternative terminology ('Type I' and 'Type II' errors) to describe the same contrasting concepts.

20 Cornia and Stewart (1993) argue that, in general the minimization of F-errors should take priority as a programme objective over the minimization of E-errors. This is in keeping with holding the reduction of poverty to be an over-riding priority. The relative appropriate balance between these errors in a specific programme will depend not only on programme designers' preferences and on the available budget but on the costs of reducing each of these types of errors. Thus, for example, Morgan (1994) argues that where administrative and institutional resources are scarce (as in much of Africa) there is reason to prefer 'broadly targeted' schemes which have some leakage over those which are more 'narrowly targeted' but require much greater use of these scarce resources. 
their families (62 per cent). Ninety-three per cent of workers in one survey reported themselves as heads of household, and received 90 per cent of their income from the SEF. Finally, statistical estimates suggest that only 13.5 per cent of SEF workers were drawn from the lowest two family income deciles. However, 77 per cent of workers appear to have been drawn from the bottom 40 per cent of the distribution of individual income, and almost half from the lowest three income deciles (Stewart and van der Geest 1995; Jorgensen et al. 1992). Thus in Bolivia SEF employment generation can be concluded to have been 'weakly' targeted in income terms, in that it reached the moderately poor, but failed to reach the truly disadvantaged. The SEF was a massive failure in attaining gender equity.

In Honduras' 'demand-driven' SIF, municipalities with a higher poverty incidence received only $\$ 5.40$ per head, whereas those with lowest incidence received $\$ 56.40$. Most cases are far less extreme, however, if still unbalanced. For example, in El Salvador's FIS, '26 per cent of resources went to the five (out of 14) poorest provinces, 46 per cent to the four richest (1990-95). This compares with an indicative allocation based on the number of poor (1990) of 38 per cent to the five poorest provinces and 30 per cent to the four richest. In a study of beneficiaries, it was estimated that 60 per cent of the beneficiaries of FIS projects were poor' (i.e. 40 per cent were non-poor) (Goodman et al. 1997). Pradhan, Rawlings and Ridder (1998) find on the basis of a careful study of pre-intervention household level data that better off households are more likely to be beneficiaries of SF investments in health, water and sanitation. A number of such examples can be readily listed, although there are also examples of seemingly more successful targeting such as Ecuador's FISE, in which only 3 per cent of loans went to the 'top 40 per cent' of municipalities (Goodman et al. 1997).

Regional imbalance is also frequently observed. Both Senegal's DIRE and AGETIP, and Ghana's PAMSCAD were significantly urban biased. Almost two-thirds of the expenditures of Senegal's AGETIP were located in the capital city and one other district (ibid). In general, Agetips appear to have been significantly urban biased. Other illustrative examples of heavy urban bias among Agetips include Chad's PADS, the Guinea Bissau SIRP and Gambia's GAMWORKS (Marc et al. 1995 and authors' fieldwork). Draper (1996) found that the FAES in Haiti allocated 69 per cent of all financial commitments and 73 per cent of projects to 3 of 9 (more accessible by road and better-off) departments containing 53 per cent of the population. The case evidence makes it difficult to conclude that SFs are successfully targeted to the poor.

Little rigorous evidence on exclusion errors of individual SFs is available. However some idea of the magnitude of errors of exclusion associated with SFs can be gained by assessing the maximum number of individuals who could be reached by SFs under optimistic scenarios, as compared with the actual numbers of the poor during adjustment. It can be seen that the proportion of the poor which SFs have reached has been small. This is surely a function both of their limited resources and, in some cases, of their inefficiency in the delivery of available benefits (i.e. E-errors). ${ }^{21}$ Proportions of

21 If SSN resources are exactly sufficient for all of the poor to be beneficiaries, and all beneficiaries cost the SSN an equal amount, then the number of F errors (in headcount terms) is exactly equal to the number of E-errors. However if SSN resources are smaller than this amount, as is typically the case, 
the population estimated to have been 'reached' in different countries range from 0.3 per cent of the population in Ghana, and 0.5 per cent in Egypt to 13 per cent in Honduras, 19 per cent in Bolivia, and 27 per cent in Mexico (UNCTAD 1994). 22 How have SFs responded to their low targeting efficiency? As mentioned earlier, this low efficiency results both from the problem of incomplete information about beneficiaries at the levels of project selection and execution, and from the differing prior capacity of communities to approach social funds in relation to their needs.

The first problem has been approached by some funds (especially the SEFs) in various ways. Where feasible, some have employed self-targeting through low wages, to ensure that the benefits of employment generation go to the neediest. To assist in selection, many SFs employ 'poverty maps' which identify the level of deprivation present in different geographical units by aggregating available data on income and access to basic social services (UNCTAD 1994). This development has become a standard practice which deserves special attention.23 Thus in Bolivia's SIF, 'urban marginal areas are ranked by their degree of coverage of basic services' (ibid). In Egypt, geographic targeting, 'based on poverty maps that are constructed using information on income, household characteristics, employment, access to basic services, and housing conditions' is used to target benefits (El Gammal 1998). In Guatemala, community costsharing requirements are applied according to a sliding scale which reflects this poverty assessment (Grinspun 1995). Attempting to reach the poor through regional targeting has severe limits however, as there are poor in 'non-poor' areas as well as non-poor in 'poor' areas. (Ravallion 1993) for instance shows that the ability to make unlimited lump-sum per-capita-income transfers between regions in Indonesia (affecting each individual in a region identically) could have at most the equivalent impact on national poverty as a 4 per cent universal increase in individual consumption. This is because transfers of this type to poor regions from rich regions necessarily make the poor in the latter worse off, placing an upper bound on the ability of this method to reduce poverty overall. Similarly, Datt and Ravallion (1993) find that the maximum impact on poverty of such transfers between Indian states is that which would be equivalently attained by increasing all persons' mean income by 1.5 per cent. They note that whereas this record might be improved by refining the basis of targeting from state to district level, such refinement might be politically difficult. These numerical estimates and structural dilemmas illustrate the potential significant weakness of regional targeting. A third targeting approach is to isolate individuals or groups with a particular visible fixed characteristic, such as women, children, the elderly and minorities. But as is well known, these characteristics may also be poorly correlated with poverty (see for instance the studies cited in Reddy and Vandemoortele 1996). These approaches have,

then the number of $F$ errors can exceed the number of E errors. If the number of E errors is fixed, then the number of $\mathrm{F}$ errors is a linearly decreasing function of programme resources.

22 These figures may include double counting due to individuals being 'reached' by more than one subproject. The definition of reached is unclear as is that of 'beneficiary'. Fergany (1994) for instance, complains of the 'extremely vague' character of the definition of 'beneficiaries' by the Egyptian SFD which leads to one-fifth of the population being officially claimed as such.

23 See Grosh (1990). Grinspun (1995) reports that this practice is much more common in Latin America than in Africa. 
however, been used by the Bolivian and Honduran SEFs, Chile's SIF, and Mexico's and Egypt's SAPs.

The problem of the differential capacity of communities to successfully formulate and present projects to SFs has been widely documented. This is likely one of the major sources of their targeting inefficiency. The phenomenon of more and better project proposals coming from less poor communities has been observed under Bolivia's SEF, in Brazil, Honduras and Nicaragua, among other places (Reddy 1998; Tendler 2000). Even where communities do successfully present project proposals, it is possible that these are priorities of community leaders or NGOs rather than genuinely of the communities themselves. In Ghana's PAMSCAD 'Community Initiatives Project' which was intended to play the role of a demand-driven SF, 'district-level officials often submitted project lists to central authorities for funding while ignoring project requests at the village level' (Kingsbury 1994). Gayi (1995) also offers a number of examples of neglect of true community priorities, because of the disproportionate influence of community leaders, in the case of PAMSCAD. 'Beneficiary assessments' of SFs have also systematically found that projects are disproportionally initiated and led by prominent local persons (for example, such an assessment in Zambia found that 58 of 60 sub-projects were initiated by one or two prominent local individuals (Owen and Van Domelen 1998). A further index of the extent to which social funds are not truly 'demand-driven' is the striking degree of ignorance of the existence of SFs, their functioning and local responsibilities which is prevalent even in communities containing sub-projects. 24

The problem of low capacities of the poor to formulate and present successful projects has been addressed by SFs in recent years. Their managers have sometimes tried to deal with the problem of low capacities on the part of the poor to formulate and present projects by consciously intervening to upgrade these skills, and to assist representatives of the poor in this process. Peru's Foncodes, Bolivia's FIS, and El Salvador's SF are said to have used active promotion of projects among communities as a means of reaching the poor (Goodman et al. 1997). Nicaragua's ESIF, for example, initiated such a programme when this deficiency became clear.25 Egypt's ESF has developed regional offices as a means of addressing this problem (UNCTAD 1994). However, the trainers hired for this purpose began to play a greater role in project identification than expected, undermining the intended 'demand-driven' character of the programme. Similarly, in Bolivia's ESF, an 'outreach unit' was established to help people prepare projects, but this was eventually changed into a 'programming' department, concerned with attaining

24 Owen and Van Domelen (1998) write for instance, 'To illustrate, in Armenia, forty-eight percent of beneficiaries asked did not know about the project; only one-third could correctly identify the social fund as the financier of the project; and only 17 percent were personally familiar with an ASIF employee. In Ecuador only one-third of beneficiaries could identify the social fund as the financing agency of the project and less than half knew how financing was obtained. An alarming 90 percent did not know who the 'witness of honour' was that signed the contract on behalf of the community.'

25 In the early stages of the ESIF, procedures were apparently so unrealistic that even government social welfare agencies were unprepared to produce project proposals at the speed and in the manner required (ibid). 
a particular mix of projects. 26 Such activity appears at least in some instances to have been successful. Bolivia's FIS is reported to have raised the percentage of its projects in poor areas through a successful outreach and promotion programme.

Another approach to the equity deficiencies of demand-driven SFs has been to construct 'hybrid' SFs in which targeted supply-driven components complement demand-driven components. Thus, Chile's FOSIS has a bank of its own projects developed according to equity criteria alongside those received from communities. Similarly, Peru's FONCODES has launched a massive school desk manufacturing programme for which it intentionally contracts only from small vendors, in addition to its demand-driven component (Grinspun 1995).

The idea of an SSN being 'demand-driven' may be a mirage in the sense that, to ease the administrative burden of selection, project managers often select only projects which conform to a number of pre-determined project types. Beneria and Mendoza (1995) found that this was the case in Honduras and wrote in this regard that 'In reality, the poor have to comply to a pre-established menu of projects if they wish to benefit from ESIF's funds'.27 This appears to be a pervasive problem of SFs which undermines their claim to being truly demand driven. Along the same lines, Tendler (1999) has argued, based on a case study in Brazil, that pressures for rapid disbursement of funds and the difficulty of financing and monitoring a large number of projects, have meant that the notion that SFs are truly 'demand-driven' and participatory has a very limited reality on the ground. As well, contractors and other indirect beneficiaries have been observed to have had great influence over community decisions leading SF evaluators to coin the phrase 'persuasion by contractor' (Tendler 2000). The variety of problems besetting the 'demand-driven' mechanism of SFs makes it evident that they would be hard pressed to disburse funds both quickly and well. Indeed, in instances where SFs have been lauded for their quick response to emergency needs, this has been only because of their relaxation of their usual requirements (in other words by becoming less characteristically SFs, particularly through becoming more 'supply' than 'demand' driven (see e.g. World Bank 2000a).

A final serious obstacle to SFs reaching the poor is the insistence of SFs on receiving 'counterpart contributions' for sub-projects. In fact contributions by communities have perversely come to be seen in much SF literature an indicator of a community's commitment in regard to a sub-project, and thereby as a sine qua non of 'participation'

26 This process interestingly parallels the development of the World Bank and other international development banks, which were initially designed to rely exclusively upon external project proposals, but due to difficulties faced by many countries in identifying and presenting effective project plans, became increasingly involved in the complete project cycle, including project identification and preparation.

27 Beneria and Mendoza (1995) found further a contradiction between the notion that social funds are 'demand-driven' and that they are to be run by expert managements operating according to wellestablished technocratic selection procedures. The latter, in their view, have tended to undermine the receptivity of social funds to truly innovative grassroots proposals. Furthermore, there may be a tension between social fund staff's role in helping in project preparation, and in engaging in 'objective' evaluation. 
(for instance, see Narayan and Ebbe 1997). Although these contributions may in principle be reduced or waived for the very poor, they are often set at a substantial level (for example 25 per cent of costs in the case of the Zambian Social Fund). Even worse, in some cases (Zambia for instance) communities willing to make bigger contributions score higher in the selection process. Further, contributions are usually required on an 'up front' basis prior to sub-project implementation. Narayan and Ebbe (1997) report that 62 per cent of World Bank sponsored SF projects require a 'community contribution' in money, land labour or materials prior to implementation. Alton (1999) finds, on the basis of a survey of World Bank project documents, a consistent discrepancy between SF target user contribution levels and actual levels, suggesting that the insistence of SFs on such contributions runs into real constraints of poor persons' ability to provide them. The evidence reviewed here suggests strongly that SFs had limited efficiency in reaching the poor.

\subsection{Long-run benefits of Social Funds}

Where SFs do undertake projects, do these generate short or long-range benefits? Clearly, this depends on the nature of the projects involved. The early SFs, which had focused on employment generation, must be judged primarily on their short-run achievements, as it is upon these that they have focussed. However, the SIFs and to a lesser extent the Agetips can be examined as to whether they have produced longer range benefits for the poor, through their investments in social infrastructure. Goodman and Morley (1998) for example argue that 'the funds deliver government services to poor communities that never had them before... and they build simple social infrastructure quite efficiently at low cost. They improve the living conditions of poor even if the measured income of the poor does not go very much up'. However, there is in fact no concrete evidence that SFs' costs of delivering such infrastructure are in fact lower than those of traditional delivery systems, even where they have primarily focused on such activities. 28 Nevertheless, to the extent that the comparatively more 'participatory' approach of SFs has led to the development of the social infrastructure which communities have most wanted and could best use, SFs may indeed be an instrument of more efficient service delivery than traditional mechanisms. Some analysts have raised questions of whether SFs have made adequate provision for the recurrent costs entailed by social investments (see, for example, the survey of such concerns in Reddy 1998). Later generations of SFs seem to have addressed this concern by requiring commitments by communities or government agencies to undertake such commitments for the future (see Narayan and Ebbe 1997). In any event, these potential long-run benefits are of little importance in cushioning the immediate social costs of adjustment.

Claims that SFs are an instrument for 'demonstrating' pathways of modernization of the traditional state apparatus are probably also highly overstated. It is almost impossible to find documented instances of the vaunted 'demonstration effect'. Additionally, although

28 For instance, Walker et al. (1999) find that although unit costs of Honduras' FHIS are 'very reasonable' compared with the industry norms, those for new water projects are 'three times that which is normally expected in other programmes'. 
the participatory approach of SFs is surely an essential element of any appropriate strategy of provision of social services in developing countries, for the reasons adduced above it cannot be the only element. In addition to the errors of exclusion which they would necessarily entail (due to the differential propensity of communities to engage in self-organization and articulation), there are further inherent limitations to the applicability of this approach, associated with the limited technical capabilities of local counterparts and communities, and asymmetries of information and incentives. Local counterparts may lack in the capability, and in some instances the incentive, to efficiently provide services to local communities. Counterparts may act to protect a monopolistic role or private and sectional interests rather than to further the larger interests of a community.

The 'multisectoral' nature of SFs has also systematically failed to be exploited productively so as to take advantage of possible complementarities between subprojects of different types (see, for example, Owen and Van Domelen 1998 on the lack of such coordination under Chile's FOSIS).

SFs may be an important long-run instrument, within a larger repertoire of options for delivering social services to the poor, and thereby for alleviating their poverty. However, it is both the case that too little evidence currently exists on which to judge this claim, and that this incrementalist and long-run motivation is a very different one from that which led to the initial development and use of SFs under the 'Washington consensus', and which it is the task of this paper to evaluate.

\section{Tentative features of comprehensive social security arrangements}

As noted, adjustment-related SFs have thus been unable to significantly offset the disequalizing impact of crises and policy reform. They may have also inadvertently diverted the attention of policymakers from the need to strengthen permanent social security systems, both as a means of dealing with endemic deprivation and as a means of contending with the sharp social costs imposed by orthodox adjustment.

Before the introduction of adjustment-related SFs, many developing countries had created a variety of safety nets comprising food subsidies, nutrition interventions, employment-based schemes and targeted transfers. Middle-income and a few lowincome countries had also achieved extensive coverage in the field of social insurance. In countries committed to fighting poverty, these programmes absorb many more resources than do SFs (2-5 per cent of GDP, excluding social insurance) and have had a large impact on job creation, income support and nutrition. Their ability to expand quickly has depended on a permanent structure of experienced staff, good portfolios of projects, clear management rules, adequate allocation of domestic resources, supplydriven execution and, with the exception of food subsidies, fairly efficient targeting. Some of the features of these 'desirable' social protection arrangements, which might be developed as a substitute or complement to SFs, are tentatively discussed hereafter. 


\subsection{Insurance-based social security programmes}

These have existed for long in all socialist economies, several countries of Latin America and a few countries of South East and East Asia. These programmes provide insurance against the risks of unemployment, sickness, invalidity, old-age, and occupational injury. Already in 1975-80 in the Southern Cone, Costa Rica and Cuba, these schemes absorbed between 5-11 per cent of GDP and covered over two-thirds of the active population (Mesa Lago 1991). In contrast, until the Asian crisis, in most 'Asian tigers' (except Malaysia) social insurance programmes were well below the level of countries with corresponding levels of GDP per capita, urbanization rate and development of the formal sector. This 'institutional underdevelopment' is arguably linked to the relatively limited need for such measures in the midst of the low unemployment experienced over three decades of fast growth, but has proven very costly during the crisis of 1997-99 (see later).

The standard Western model of social security comprising both public and private provision of insurance for life-event contingencies is of little applicability to lowincome countries with a small formal sector and a large share of the workforce in agriculture. To start with, the causes of poverty in these countries differ from those of the industrialized countries and are unlikely to be removed by insurance-based interventions. Secondly, private markets for risk insurance are still underdeveloped. Thirdly, insurance-based schemes generally cover only the civil servants and the industrial 'labour elite' and bypass the self-employed. Finally, their typical institutional form entails unit costs per capita which prevent their extension on a non-contributory basis. Unless drastically adapted, therefore, this insurance-based model cannot protect much of the population of low-income countries from major contingent and idiosyncratic shocks.

Yet, there are examples of adaptations of formal arrangements to low-income rural settings that have overcome the limitations of the 'Western social insurance model' and developed a low-cost, non-contributory, state-funded scheme providing coverage against key risks of immiseration arising from old age, sickness, disability, injury and widowhood. In developing countries, these risks are a main factor in chronic poverty that cannot be tackled by increasing access to employment. The Kerala non-contributory pension scheme, for instance, covers almost all the elderly poor, while some form of social assistance is available to half the workers in the unorganized sector (Guhan 1995). The Tamil Nadu programme, in turn, includes social pensions for old age, agricultural labourers, widows and the physically handicapped, as well as survivor benefits, maternity assistance and accident relief. All the households below the poverty line are eligible-except in the case of pensions where the means-testing is more stringent. An estimated 17 per cent of poor households in Tamil Nadu are covered by this programme, and nearly 60 per cent of the beneficiaries are women. A detailed evaluation suggests that the targeting efficiency of the programme is high, moral hazard does not pose a problem and overheads are low. On all accounts, such contingencyrelated social assistance have better cost-benefit ratios than many other safety nets, including self-targeted employment programmes (ibid). Guhan (1992) estimates that the extension of such a minimum social assistance package to all poor households of India with these characteristics would cost only 0.3 per cent of the national GDP. 


\subsection{Employment-based safety nets}

Employment-based safety nets are an instrument which can effectively reach needy but able people of working age. Several arguments justify the adoption of public work schemes over pure transfer programmes. To start with, public work programmes not only permit the achievement of specific poverty alleviation objectives over the short run, but also contribute to the growth of productivity and poverty alleviation over the long term by speeding up capital formation, particularly if the infrastructure so created benefits mostly the poor. In addition, they are less affected by the adverse selection problems associated with direct transfer programmes. Three of the best known public work schemes are briefly reviewed hereafter.

The Maharastra Employment Guarantee Scheme (MEGS) was launched on occasion of the crop failure of 1972-73 (Drèze 1990). In 1983, the programme was replicated nationwide and was later merged in the Jawahar Rozgar Yojana, possibly the largest employment programme of this type in the world (Stewart and van der Geest 1995). Over 1972-73, MEGS created one billion person-days of employment (corresponding to year-round full-employment for almost five million people). As Drèze notes (p. 89), 'Even though real wages were very meagre, the contribution of relief works to total village income in 1972-73 was often enormous'. With the recovery of the rural economy, the programme was scaled back, but during 1988-93, it still created 80 to 120 million days of employment per year, thus helping to avert the most acute forms of transitory and chronic poverty (Guhan 1995). During this period, MEGS counted on sizeable domestic resources (equal to 10 per cent of the state development expenditure) and absorbed around 3 per cent of the rural workforce.

Chile's Minimum Employment Programme (PEM) was instituted in 1975 in the face of a major recession. In 1976 it covered 5.2 per cent of the labour force and reached its peak during the 1982-83 recession when together with the Occupational Scheme for Heads of Households (POJH), it covered no less than 13 per cent of the labour force or 40 per cent of the jobless (Raczynski 1988; World Bank 1990) at a total budgetary cost equal to 1.4 per cent of GDP. Both programmes were well targeted and appear to have played an important role in family survival despite the low value of the subsidy they provided.

Public works-based safety nets proved successful also in Botswana where the government adopted extensive measures to combat the collapse of diamond exports of 1981-82 and the droughts of 1981-82 and 1985-86 (Quinn et al. 1988). The government's response focused on supplementary feeding, nutritional treatment of malnourished children and a Labour-Based Relief Programme (LBRP). The latter comprised a series of labour-intensive projects such as the building or rehabilitation of roads, dams, livestock wells and pit latrines. At the peak, in 1985/6, LBRP provided 74,000 workplaces, a number almost equivalent to the jobs estimated to have been lost in the rural economy, and replaced 35 per cent of the income lost by households. The total cost of this large-scale programme in the peak year was 2 per cent of GDP. If food aid is factored in, the total value of the Drought Relief Programme doubled. 


\subsection{Consumer subsidies}

Prior to the introduction of adjustment programmes, many developing and all socialist economies possessed a variety of subsidy schemes aiming at guaranteeing access by the poor to basic items. In urban South Asia the subsidy took the form of targeted rations sold to low-income people at 'fair price' shops. Generalized wheat or tortilla subsidies were available in Brazil, Egypt, Morocco and Mexico. Generalized food subsidies on grains, cooking oil and sugar have been the most common.

The literature has emphasized that even generalized food subsidies-which are often poorly targeted though they are fairly easy to administer-do help the poor: indeed, while the non-poor capture a larger share of the total subsidy, the transfer represents a greater share of the income of the poor than of that of the non-poor (Ahmed 1998). In spite of this, because of their fiscal cost, poor targeting, low transfer efficiency and distortions caused to relative prices, these programmes have been sharply reduced in many countries. Food subsidies targeted by broad criteria (distribution of inferior commodities disfavoured by the non-poor, access limited to poor areas, schoolchildren, nursing mothers and so on) and direct nutritional interventions constitute, in contrast, cost-effective transfers that, once in place, can be expanded to protect the poor during downturns or sharp price adjustments (Chu and Gupta 1998, chapter 2).

\section{Conclusions and policy recommendations}

SFs have been projected as capable of much larger tasks than they have in fact been able to fulfil. Why in this light have SFs been so alluring to decisionmakers? The answer lies in the heady mixture provided by their political utility, the ease with which they provide a simplified 'development narrative offering convincing and simple explanations for the causes of certain problems and providing appealing blueprints for action' (Tendler (2000), the complementarity between this narrative and a general scepticism of the role of the state, and a belief that policy reforms which cause damage to some can still be 'beneficial for all' with suitable compensation (into which, however, little thought is put).

Notwithstanding the visibility and appeal they enjoyed with national and international decisionmakers, SFs played a minor role in reducing the number of adjustment- and chronic-poor, and in reversing the adverse distributive and poverty shifts entailed by stabilization. The number of jobs added to the economy was generally less than a meagre 1.0 per cent of total employment. In addition, SFs often allocated their expenditures not to the poorest groups and activities with high social benefits but rather to programmes that required little preparation and were perceived as having large demonstration effects, often political in nature. Indeed, the targeting precision of SFs has been lower than that of the more effective traditional safety nets. One of the causes of this phenomenon was their 'demand-driven' nature, which often limits the access to resources of the very poor, who have a limited capacity to articulate their demands formally and to mobilize counterpart funds. 
SFs have thus proven to be no panacea. Greater impact on poverty and inequality would have required much larger resources, more permanent relief structures established prior to crisis, improved planning and targeting, and more moderate reliance on 'demanddriven' mechanisms. SFs should be viewed, at best, as a partial corrective to the social costs and inequality generated by 'orthodox' forms of macroeconomic adjustment. A real impact on poverty and inequality would have required a different approach to the adjustment process itself. It is reasonable to believe that ex ante macroeconomic policy decisions have a greater impact on employment, inequality and poverty than the implementation ex post of SFs. In the absence of an alternative approach to adjustment, however, permanent social security arrangements would have more effectively provided social protection to the poor and contained increases in inequality. To the extent that the misplaced focus on SFs as a compensatory tool deflects attention from the development of such alternative devices, SFs have been especially damaging.

In light of these observations, we recommend that further efforts to address poverty and distributional concerns in future policy reform programmes take into consideration the following points:

i) Sustainable and equitable poverty reduction requires a series of measures, including a macroeconomic policy attentive to its social impact, sustained investments in social programmes, and the development of flexible but permanent social safety nets which are well integrated in a nationwide social protection and development framework.

ii) Adjustment programmes should strive to avoid large initial expenditure cuts and explore stabilization trajectories ensuring macroeconomic stability at lower social costs. The experience reviewed in this paper is that large initial social cuts were only in a small number of cases reversed by the launch, years later, of SFs. Despite its loud rhetoric in regard to poverty alleviation, few organizational changes were effected at the World Bank to meet this challenge, mobilize adequate funds or modify the orthodox position on key adjustment policies such as budgetary retrenchments, removal of subsides, sharp hikes in interest rates and so on, which have been shown to have a large effect on poverty and inequality.

iii) It is essential during normal times to develop permanent and cost-effective social_security systems. As the Indian experience shows, this is feasible even in low-income and rural settings. Cost-efficient permanent arrangements of this type are more likely to contain the social costs of severe crises than hastily arranged temporary SFs. Creating permanent, and yet flexible social safety nets, should thus be a priority of governments, the Bretton Woods Institutions and the ILO. These social safety nets should be designed so as to supply social protection as and when required and at low marginal costs. Ad hoc SFs should be established mainly in the case of exceptional contingencies, such as when sharply rising social demands combine with circumstances in which an overly rapid expansion of existing social institutions and arrangements would risk crippling them.

Relevant safety nets need to be introduced concurrently with adjustment programmes or preferably prior to their launch - and not years after these have 
been in operation - both because of the human costs generated by such delay and because increases in poverty and unemployment which may occur immediately after adjustment can became self-reinforcing and difficult to reverse. One way to minimize response times is to entrust the responsibility for these interventions to permanent institutional structures counting on a welltested response infrastructure. Such institutions have a role in normal as well as crisis years, so as to provide security to those who require it at all times, so as to ensure the adequate functioning of the institutional infrastructure, and so as to accumulate and safeguard administrative and financial resources for when they are most needed.

iv) During periods of crisis and adjustment, social safety nets need to be allocated adequate resources. It will be virtually impossible to achieve nationwide social protection objectives with the resources allocated to SFs in recent years.

v) Finally, the targeting of social protection programmes should aim not only at reducing programme 'leakage' but also at minimizing the exclusion of the poor. Where demand-driven programmes exist, they should be combined with outreach programmes aiming at reaching the poorest.

Countries faced by the need for significant policy changes will do well to learn from the chequered experience with SFs outlined here and to invest in the development of comprehensive social security arrangements which can lessen the potential human toll of such changes, as well as, more fundamentally, pursue alternative approaches to economic policy reform itself. Such change is unlikely to be the result of shifting intellectual currents alone. It will also be the outcome of social demands and of political imagination.

\section{References}

Ahmed (1998). In K. Y. Chu and S. Gupta (eds), Social Safety Nets: Issues and Recent Experiences. Washington, DC: IMF.

Alarcon, D. and T. McKinley (1995). 'Widening Wage Dispersion Under Structural Adjustment in Mexico'. Discussion Paper No. Fc 1995-4. Toronto: University of Toronto

Alton, G. (1999). 'Social Funds Performance: A Review'. Washington, DC: World Bank. Mimeo.

Atkinson, A. (1995). 'Income Distribution in the OECD Countries: Evidence from the Luxembourg Income study’. Paris: OECD

Barro, R. (1991). 'Economic Growth in a Cross-Section of Countries'. Quarterly Journal of Economics, 106: 407-43.

Behrman, J., N. Birdsall and M. Szekely (2000). 'Economic Reform and Wage Differentials in Latin America'. Working Paper 435. Washington, DC: InterAmerican Development Bank, Research Department. 
Benería, L. and B. Mendoza (1995). 'Structural Adjustment and Social Emergency Funds: The Cases of Honduras, Mexico and Nicaragua. The European Journal of Development Research, 7 (1): 53-76.

Besley, T. and R. Kanbur (1988). 'Food Subsidies and Poverty Alleviation'. Economic Journal, 98.

Bourguignon, F. and C. Morisson (1990). 'Income distribution, Development and Foreign Trade: A Cross Sectional Analysis'. European Economic Review, 34: 1113-32.

Carvalho, S. (1999). 'Social Funds: Guidelines for Design and Implementation'. Washington, DC: World Bank. Mimeo.

Chu, K. Y. and S. Gupta (1998). Social Safety Nets: Issues and Recent Experiences. Washington, DC: IMF.

Cornia, G. A. (1999). 'Social Funds in Stabilization and Adjustment Programmes'. WIDER Research for Action, No. 48. Helsinki: UNU/WIDER

Cornia G. A. and F. Stewart (1993). 'Two Errors of Targeting'. Innocenti Occasional Papers No. 36. Special Subseries: Fiscal Policy and the Poor. Florence: UNICEF International Child Development Centre.

Cornia G. A. with S. Kiiski (2001). 'Trends in Income Distribution in the Post- World War II Period: Evidence and Interpretation'. WIDER Discussion Paper (forthcoming). Helsinki: UNU/WIDER.

Cornia, G. A., R. Jolly and F. Stewart (eds) (1987). Adjustment with a Human Face: Protecting the Vulnerable and Promoting Growth. 2 vols. Oxford: Clarendon Press.

Datt, G. and M. Ravallion (1993). 'Regional Disparities, Targeting and Poverty in India', in M. Lipton and J. van der Gaag (eds), Including the Poor. Washington, DC: World Bank.

Draper, M. (1996). 'Social Investment Funds Study: Country Case Report, Haiti'. Washington, DC: Inter-American Development Bank. Mimeo.

Drèze, J. (1990). 'Famine Prevention in India', in J. Drèze and A. Sen (eds), The Political Economy of Hunger, volume II. WIDER Studies in Development Economics. Oxford: Oxford University Press.

El Gammal, H. (2000) 'The Role of Social Funds for Development: Egypt's Experience', www.worldbank.org/wbi/mdf/mdfl/role.htm .

Fergany, N. (1994). 'On the Impact of Economic Restructuring on Human Development and Proposed Strategies to Alleviate Poverty: The Case of Egypt. Geneva: UNRISD. Mimeo.

Galbraith, J. and J. Lu (1999). 'Inequality and Financial Crises: Some Early Findings'. Paper prepared for the Hyman Minsky Conference on Financial Economics, Jerome Levy Economics Institute of Bard College, New York, April 21-23. 
Gayi, Samuel K. (1995). 'Adjusting to the Social Costs of Adjustment in Ghana: Problems and Prospects'. The European Journal of Development Research, 7 (1): 77 100.

Glaessner, P. et al. (1994). 'Poverty Alleviation and Social Investment Funds: The Latin American Experience'. World Bank Discussion Paper No. 261. Washington, DC: World Bank.

Goodman, M. and S. Morley (1998). 'The Inter-American Development Bank's Study of Social Funds', in A. G. Bigio (ed.), Social Funds and Reaching the Poor: Experiences and Future Directions. Washington, DC: World Bank.

Goodman, M. et al. (1997). 'Social Investment Funds in Latin America: Past Performance and Future Role'. Washington, DC: Inter-American Development Bank.

Gottschalk, P. and T. Smeeding (1997). 'Cross-National Comparison of Earnings and Income Inequality'. Journal of Economic Literature, 35: 633-87.

Graham, C. (1994). Safety Nets, Politics, and the Poor: Transition to Market Economies. Washington, DC: The Brookings Institute.

Grinspun, A. J. (1995). 'Social Funds: Fertile Ground for South-South Cooperation'. Cooperation South, May.

Grosh, M. E. (1990). 'AWhat Should Social Funds Finance?: Portfolio Mix, Targeting, and Efficiency Criteria'. View from LATHR No. 3. Washington, DC: World Bank Human Resource Division, Technical Department, Latin America and Caribbean.

Guhan, S. (1992). 'Social Security for the Unorganized Poor: A Feasible Blueprint for India'. Discussion Paper. Bombay: UNDP and Indira Gandhi Institute of Development Research.

Guhan, S. (1995). 'Social security options for developing countries'. In Reducing Poverty through Labour Market Policies: A Contribution to the World Summit for Social Development, edited by J. Figueredo and Z. Shaheed. Geneva: International Institute for Labour Studies.

Harrison, A. and G. Hanson (1999). 'Who Gains from Trade Reform? Some Remaining Puzzles'. Journal of Development Economics, 59.

Iglesias, E. (1998). 'Income Distribution and Sustainable Growth: A Latin American Perspective', in V. Tanzi and Ke-Young Chu (eds), Income Distribution and HighQuality Growth. Cambridge: MIT Press.

ILO (1992). Stabilization, Structural Adjustment and Social Policies in Costa Rica: the Role of Compensatory Programmes. Occasional Paper No. 1. Interdepartmental Project on Structural Adjustment. Geneva: ILO.

IMF (1998). 'External Evaluation of the ESAF'. Report by a Group of Independent Experts. Washington, DC: IMF. 
Jayarajah, C., W. Branson and B. Sen (1996). Social Dimensions of Adjustment: World Bank Experience, 1980-93. A World Bank Operations Evaluation Study. Washington, DC: World Bank.

Jespersen, E. (1992). 'External Shocks, Adjustment Policies and Economic and Social Performance', in G. A. Cornia, R. van der Hoeven and T. Mkandawire (eds), Africa's Recovery in the 1990s: from Stagnation and Adjustment to Human Development. Basingstokes: Macmillan.

Johnson O. and J. Salop (1980). 'Distributional Aspects of Stabilization Programs in Developing Countries'. IMF Staff Papers. Washington, DC: IMF.

Jorgensen, S., M. Grosh and M. Schacter (1992). Bolivia's Answer to Poverty, Economic Crisis, and Adjustment: The Emergency Social Fund. World Bank Regional and Sectoral Studies. Washington, DC: World Bank.

Kanbur, R. (1998). 'Income Distribution and Development'. World Bank WP 98-13. Washington, DC: World Bank.

Kanbur, R. and N. Lustig (1999). 'Why is Inequality Back on the Agenda?' Paper presented at the Annual Bank Conference on Development Economics. Washington, DC: World Bank, April 28-30

Kingsbury, D. (1994). 'Compensatory Social Programs and Structural Adjustment: A Review of Experience'. AID Evaluation Special Study No. 72. Arlington, VA: US Agency for International Development.

Krugman, P. and L. Taylor (1978). 'Contractionary Effects of Devaluation'. Journal of International Economics, 8: 445-56.

Marc, A. et al. (1995). 'Social Action Programmes and Social Funds: A Review of Adjustment and Implementation in Sub-Saharan Africa'. World Bank Discussion Papers No. 275. Washington, DC: World Bank.

Marshall, K. (1992). 'The Genesis and Early Debates', in S. Jorgensen, M. Grosh and M. Schacter (eds), Bolivia's Answer to Poverty, Economic Crisis, and Adjustment: The Emergency Social Fund. World Bank Regional and Sectoral Studies. Washington, DC: World Bank.

Mesa Lago, C. (1991). 'Social Security in Latin America and the Caribbean: A Comparative Assessment', in E. Ahmad, J. Drèze, J. Hills and A. Sen (eds), Social Security in Developing Countries. WIDER Studies in Development Economics. Oxford: Oxford University Press.

Morgan, R. (1994). 'Safety Nets, Targeting and Poverty-Oriented Development Planning: Some Considerations (with reference to Eastern and Southern Africa)'. Background Discussion paper for World Bank/EDI Regional Workshop on Integration of Poverty Alleviation Strategies into Economic Policies, Blantyre, Malawi. July. Nairobi: UNICEF Eastern and Southern African Regional Office.

Morley, S. (2000). 'Distribution and Growth in Latin America in an Era of Structural Reform'. Paper presented at the Conference on 'Poverty and Inequality in 
Developing Countries: A Policy Dialogue on the Effects of Globalization' organized by the OECD Development Centre, Paris, 30 November-1 December.

Narayan, D. and K. Ebbe (1997). 'Design of Social Funds: Participation, Demand Orientation, and Local Organizational Capacity'. World Bank Discussion Paper No. 375. Washington, DC: World Bank.

Newman, J. et al. (1992). 'How Did Workers Benefit?', in S. Jorgensen, M. Grosh and M. Schacter (eds), Bolivia's Answer to Poverty, Economic Crisis, and Adjustment: The Emergency Social Fund. World Bank Regional and Sectoral Studies. Washington, DC: World Bank.

Owen, D. and J. van Domelen (1998). 'Getting an Earful: A Review of Beneficiary Assessments of Social Funds'. Washington, DC: Human Development Network, World Bank. Mimeo.

Pradhan, M., L. Rawlings and G. Ridder (1998). 'The Bolivian Social Investment Fund: An Analysis of Baseline Data for Impact Evaluation'. The World Bank Economic Review, 12 (3).

Quinn, V., M. Cohen, J. Mason and B. N. Kgosidintsi (1988). 'Crisis-proofing the Economy: The Response of Botswana to Economic Recession and Drought', in G. A. Cornia, R. Jolly and F. Stewart (eds), Adjustment with a Human Face: Ten Country Case Studies. Oxford: Oxford University Press.

Raczynski, D. (1988). 'Social policy, Poverty, and Vulnerable Groups: Children in Chile', in G. A. Cornia, R. Jolly and F. Stewart (eds), Adjustment with a Human Face: Ten Country Case Studies. Oxford: Oxford University Press.

Ravallion, M. (1993). 'Poverty Alleviation Through Regional Targeting: A Case Study of Indonesia', in K. Hoff, A. Braverman, and J. E. Stiglitz (eds), The Economics of Rural Organization: Theory, Practice and Policy. Oxford: Oxford University Press.

Reddy, S. (1998). Social Funds in Developing Countries: Recent Experiences and Lessons. Unicef Staff Working Paper No. EPP-EVL-98-002. New York: Office of Evaluation Policy and Planning, Unicef-NY.

Reddy, S. and A. Dube (2000). 'Liberalization, Income Distribution and Political Economy: The Bargaining Channel'. Cambridge, MA: Harvard University. Mimeo.

Reddy, S. and J. Vandemoortele (1996). 'User Financing of Basic Social Services'. UNICEF Staff Working Papers. Evaluation, Policy and Planning Series. New York: UNICEF.

Robbins, D. (1995). 'Earnings Dispersion in Chile after Trade Liberalization'. Cambridge, MA: Harvard University. Mimeo.

Rodriguez, F. and D. Rodrik (2000). 'Trade Policy and Economic Growth: A Skeptic's Guide to the Cross-National Evidence'. Cambridge, MA: John F. Kennedy School of Government, Harvard University. Unpublished manuscript.

Rodrik, D. (1997). Has Globalization Gone Too Far? Washington, DC: Institute for International Economics. 
Sachs, J. and A. Warner (1995). 'Economic Reform and the Process of Global Integration'. Brookings Papers on Economic Activity, 1: 1-118.

Sen, A. (1994) 'The Political Economy of Targeting'. Paper presented at the Annual Bank Conference on Development Economics. Washington, DC: World Bank. Mimeo.

Stewart, F. and W. van der Geest (1995). 'Adjustment and Social Funds: Political Panacea or Effective Poverty Reduction?' Employment Papers No. 2. Geneva: Employment Department, ILO.

Stiglitz, J. (1998). 'More Instruments and Broader Goals: Moving toward the PostWashington Consensus'. WIDER Annual Lectures, 2. Helsinki: UNU/WIDER.

Taylor, L. (2001). 'External Liberalization, Economic Performance, and Distribution in Latin America and Elsewhere'. WIDER Working Papers, No. 215. Helsinki: UNU/WIDER.

Tendler, J. (2000). 'Why Are Social Funds So Popular?', forthcoming in S. Yusuf, W. $\mathrm{Wu}$ and S. Everett (eds), Local Dynamics in the Era of Globalization. Oxford: Oxford University Press.

Tendler, J. with R. Serrano (1999). The Rise of Social Funds: What Are They a Model Of?, Cambridge, MA: Dept. of Urban Studies and Planning, Massachusetts Institute of Technology.

UNCTAD (1994). 'Recent Developments in Social Funds and Safety Nets: Background Note by the UNCTAD Secretariat'. UNCTAD/PA/2. Standing Committee on Poverty Alleviation. Intergovernmental Group of Experts on Poverty Alleviation, Geneva, 24 January 1994. Item 3 of the Provisional Agenda. New York: United Nations.

UNCTAD (1997). Trade and Development Report. Geneva: UNCTAD.

Virak, Y. (2000). 'A Reflection on the Social Funds in Cambodia'. http://aric.adb.org/conference/msf/papers/cam2-w8_2.htm

Walker, I. et al. (1999). 'Ex-Post Evaluation of the Honduran Social Investment Fund'. Washington, DC: World Bank. Mimeo.

Wood, Adrian (1994). North-South Trade, Employment and Inequality. Oxford: Clarendon Press.

World Bank (1986). 'Financing Adjustment with Growth in sub-Saharan Africa, 198690'. Washington, DC: World Bank.

World Bank (1990). World Development Report 1990 - Poverty. New York: Oxford University Press for the World Bank.

World Bank (1997). 'Portfolio Improvement Program: Review of the Social Funds Portfolio'. Washington, DC: World Bank.

World Bank (1998). 'Social Funds 2000 Impact Evaluation: Updated Midstream Issues Paper'. Washington, DC: World Bank. Mimeo. 
World Bank (2000a). 'Coping with Natural Disasters: Role of Social Funds'. http://wbln0018.worldbank.org/HDNet/HDdocs.nsf.

World Bank (2000b). World Development Report 2000-1. New York: Oxford University Press for the World Bank. 
UNU World Institute for Development Economics Research (UNU/WIDER) was established by the United Nations University as its first research and training centre and started work in Helsinki, Finland in 1985. The purpose of the Institute is to undertake applied research and policy analysis on structural changes affecting the developing and transitional economies, to provide a forum for the advocacy of policies leading to robust, equitable and environmentally sustainable growth, and to promote capacity strengthening and training in the field of economic and social policy making. Its work is carried out by staff researchers and visiting scholars in Helsinki and through networks of collaborating scholars and institutions around the world.

UNU World Institute for Development Economics Research (UNU/WIDER)

Katajanokanlaituri 6 B, 00160 Helsinki, Finland

Camera-ready typescript prepared by Liisa Roponen at UNU/WIDER

Printed at UNU/WIDER, Helsinki

The views expressed in this publication are those of the author(s). Publication does not imply endorsement by the Institute or the United Nations University, nor by the programme/project sponsors, of any of the views expressed.

ISSN 1609-5774

ISBN 952-455-126-8 (printed publication)

ISBN 952-455-127-6 (internet publication) 